\title{
PLANEJAMENTO ORÇAMENTÁRIO E GESTÃO GOVERNAMENTAL
}

O planejamento da ação governamental, especialmente na modalidade de planejamento orçamentário da administração pública - na forma do que já se expôs anteriormente -, guarda um estreito vínculo com a gestão pública, ${ }^{1}$ tendo o sistema orçamentário papel fundamental na viabilização do planejamento.

A construção do sistema orçamentário é uma tarefa extremamente complexa, pois exige uma compatibilização de institutos e conceitos de várias áreas do conhecimento, uma vez que há de compreender em sua estruturação, de forma harmônica, aspectos jurídicos, econômicos, contábeis e de administração pública, entre outros.

Além disso, envolve a combinação de informações de múltiplas fontes, com diferentes perspectivas, envolvendo múltiplos grupos de interesse, todos influenciando a tomada de decisões complexas, ${ }^{2}$ o que justifica a evolução e a variedade de técnicas orçamentárias que procuram compatibilizar todas essas variáveis e aperfeiçoar os orçamentos públicos, com os consequentes reflexos para o planejamento e a gestão, como se explicitará a seguir.

A atividade planejadora é abrangente, podendo-se nela constatar, entre suas várias características, a complexidade, dada a "multiplicidade de elementos que a

1 "A budget is not only a tool of macroeconomic policy but also a management mechanism" (SHAH, Anwar; SHEN, Chunli. A primer on performance budgeting. In: SHAH, Anwar (Ed.). Budgeting and budgetary institutions, p. 138).

2 FÖLSCHER, Alta. Budget methods and practices. In: SHAH, Anwar (Ed.). Budgeting and budgetary institutions, p. 138. 
constituem, de seu procedimento, dos diversos interesses que envolvem e dos inúmeros sujeitos que dela participam", a orientação finalistica, "na medida em que intenciona concretizar finalidades públicas e objetivos específicos”, a seletividade, dada a necessidade de seus resultados dependerem de um objeto bem definido, que deve ser claro, específico e exequível, a flexibilidade, com a "possibilidade de alteração e correção contínua do processo de planejamento e dos produtos desse processo", que "permitirá retificar efeitos indesejados do planejamento e corrigir seus rumos no intuito de atingir os objetivos públicos esperados", de tal modo que preserve "uma proteção mínima de segurança jurídica dos afetados pelo plano e, de outro lado, um grau adequado de discricionariedade decisória da autoridade pública para atingir os objetivos públicos que dependam do planejamento estatal". ${ }^{3}$

O planejamento orçamentário governamental se materializa, tanto em termos jurídicos, pelas normas que o veiculam, quanto no aspecto administrativo-gerencial, por meio de diversos conceitos e técnicas em permanente evolução, sobre os quais é importante discorrer, com a finalidade de permitir uma melhor compreensão do tema.

A multidisciplinaridade - são várias as áreas do conhecimento envolvidas, como já mencionado, - e a interdisciplinaridade - essas áreas se conectam e estão relacionadas - do tema, associada às particularidades de cada região, país, organização, entidade que dele faz ou fez uso, impedem que a análise, tanto no aspecto da evolução histórica quanto da sua própria sistematização, venha a ser feita com a didática e precisão ideais, de modo que se constata haver no mais das vezes alguma imprecisão em conceitos que apresentam significativo grau de inter-relação, não sendo sempre possível distingui-los com a clareza desejável. Mesmo assim, uma clarificação e melhor delimitação permitem um aprofundamento no conhecimento do tema e em suas peculiaridades.

\subsection{O PLANEJAMENTO ORÇAMENTÁRIO, OS ORÇAMENTOS PÚBLICOS E A GESTÃO | A EVOLUÇÃO DAS TÉCNICAS ORÇAMENTÁRIAS E MODELOS DE ORÇAMENTAÇÃO}

Desde que se admite terem surgido as primeiras normas que deram origem à ideia de controle das despesas públicas, registrando-se como marco importante

Como destacado com propriedade por: MARRARA, Thiago. A atividade de planejamento na Administração Pública: o papel e o conteúdo das normas previstas no anteprojeto da nova lei de organização administrativa. Revista Eletrônica de Direito do Estado da Bahia, p. 4-5. 
o art. 12 da Magna Carta de 1215, já transcrito, ${ }^{4}$ começaram a aparecer os incipientes orçamentos públicos e se desenvolver as técnicas mais adequadas para construí-los.

Fica clara a necessidade de os Estados terem instrumentos com os quais possam organizar suas finanças, regulamentando a arrecadação, a administração e o gasto dos recursos públicos. No entanto, decorreu longo tempo até que técnicas começassem a ser desenvolvidas de modo a permitir que se estruturassem peças com características efetivas de um orçamento público. Jesse Burkhead, em sua clássica obra sobre o tema, ao historiar a evolução do orçamento nos Estados Unidos, registra, mostrando a precariedade ainda presente na época da Revolução Americana, que:

"O sistema orçamentário da Grã-Bretanha ainda não estava inteiramente desenvolvido à época da Revolução Americana. Não havia, portanto, uma técnica orçamentária consagrada, na Grã-Bretanha, passível de imitação por parte dos arquitetos da Constituição. Assim, a Constituição exige apenas que 'nenhuma soma será retirada do Tesouro, senão em consequência de apropriações estabelecidas em lei; e que um balanço das entradas e saídas de dinheiros públicos deve ser divulgado, periódicamente’ (art. I, seção 9)".

Jesse Burkhead faz menção ao ano de 1822 como o marco do início do orçamento, ${ }^{6}$ ano em que o Chanceler do Erário britânico passou a expor ao Parlamento sobre a situação das finanças públicas, tendo em vista a necessidade de justificar as receitas e as despesas que compunham o fundo geral criado em 1787 para gerenciar as atividades financeiras do Governo. ${ }^{7}$

Os primeiros documentos com natureza de orçamentos públicos tinham características essencialmente de peças contábeis, basicamente com a finalidade de registrar as receitas e despesas, configurando o que se pode chamar concepção clássica do orçamento, como já mencionamos anteriormente. ${ }^{8}$

4 Vide "Capítulo 1", nota de rodapé 2.

5 BURKHEAD, Jesse. Orçamento público, p. 12.

6 Como já mencionei, em breve histórico, na obra "Autonomia Financeira do Poder Judiciário", p. 57-59, em parte reproduzida aqui.

7 BURKHEAD, Jesse. Orçamento público, p. 4.

8 Vide Capítulo 1. Ou, em outras palavras e contexto, na bem lançada explicação de José Afonso da Silva, "O orçamento clássico, cuja origem se identifica com a das instituições democráticas representativas, era uma peça de previsão das receitas e autorização das despesas públicas, classificadas estas por objeto, sem se cogitar das necessidades reais da administração e da população, nem dos objetivos econômico-sociais a atingir com sua execução" (Orçamento-programa no Brasil, p. 1). 
A evolução do próprio Estado, com o aumento de sua dimensão e a ampliação de suas funções, levou a uma necessidade de aperfeiçoamento da administração pública, inclusive e especialmente no âmbito das técnicas orçamentárias, o que foi aos poucos modificando essa concepção clássica do orçamento, que passou a assumir uma função mais efetiva no planejamento da ação governamental e condução das políticas públicas, até mesmo em decorrência do crescente intervencionismo do Estado nas atividades sociais e econômicas. Passa a ser "un instrumento mediante el cual el Estado actúa sobre la Economía", nas precisas e bem colocadas palavras de Giuliani Fonrouge.?

Momento importante a merecer registro na evolução das técnicas orçamentárias e na mudança da concepção do orçamento ocorreu no período de 1909 a 1912, com os trabalhos realizados no governo norte-americano pela Comissão Taft. Com a posse do Presidente William Howard Taft, e os problemas de déficit público encontrados, entre outros na administração pública, criou-se em 1910 a Comissão de Economia e Eficiência, que ficou conhecida como Comissão Taft. Esta realizou estudos sobre o orçamento público, a organização e as atividades do governo federal, os problemas de pessoal, a contabilidade pública e a utilização de métodos empresariais no setor público, ${ }^{10}$ que resultaram na divulgação, em 1912, de uma mensagem do Presidente e de um relatório da Comissão. Entre os inúmeros pontos importantes abordados pelos referidos documentos, interessa destacar o trecho do relatório da Comissão que reconhece a importância da eficiência e da mensuração de custos e resultados no serviço público:

"A fim de que se possa pensar com clareza sobre o problema de sua responsabilidade, o administrador precisa ter diante de si dados que reflitam resultados, em termos de qualidade e quantidade; precisa estar habilitado a medir a qualidade e a quantidade dos resultados por unidades de custo e de eficiência". ${ }^{11}$

Mas o incremento das técnicas de planejamento orçamentário intensificou-se a partir do período pós-Segunda Guerra Mundial, especialmente na década de 1950, em que a necessidade de reconstrução dos países afetados levou à implantação de planos econômicos com aporte de recursos, cuja viabilização incentivou o aperfeiçoamento dos sistemas até então existentes de planejamento econômico e orçamentário governamentais.

Em 1946, a partir do orçamento apresentado pela Marinha norte-americana para o ano de 1948, o Departamento de Defesa promoveu aperfeiçoamentos nas

GIULIANI FONROUGE, Carlos M. Derecho financiero, p. 145.

10 BURKHEAD, Jesse. Orçamento público, p. 23-24.

11 HOUSE Doc. n. 854, p. 4-5, apud BURKHEAD, Jesse. Orçamento público, p. 26. 
técnicas de contabilização orçamentária que influenciaram a Comissão de Organização do Setor Executivo do Governo, conhecida como Comissão Hoover. Com outros órgãos do governo norte-americano - Bureau de Orçamento, Contadoria Geral, Departamento do Tesouro -, aperfeiçoou as normas contábeis do governo federal. A Comissão Hoover, em sua primeira formação, ao produzir recomendações para uma profunda reforma orçamentária, e em seu relatório sobre a Técnica Orçamentária e Contabilidade, menciona a expressão que acabou se consagrando como representante de uma nova modalidade de orçamento: o performance budget, ou orçamento de desempenho. Foi divulgada a seguinte recomendação (Recomendação n. 1): "Recomendamos que o conceito de orçamento do Governo Federal seja inteiramente reformulado pela adoção de um orçamento baseado em funçôes, atividades e projetos: a isto denominamos orçamento de desempenho". ${ }^{12}$

Passaram a se desenvolver com maior ênfase os conceitos, os processos e as técnicas orçamentárias, de planejamento e de gestão, que passaram a incorporar essas funções mais modernas dos orçamentos públicos, dando origem aos modelos de "orçamento funcional", "orçamento-programa”, "orçamento de desempenho (performance budget)", "PPBS (Planning, Programming, and Budgeting System)”, e, mais recentemente, planejamento estratégico (que serão mais bem analisados oportunamente - item 2.2, que sepultam a concepção clássica de orçamento e passam a reconhecê-lo e fazer dele um instrumento essencial e central para o planejamento e a gestão governamentais, além de aspecto fundamental para a transparência e a democratização do gasto público.

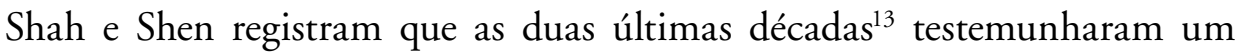
crescente interesse na gestão por desempenho e nas reformas orçamentárias, como resposta às cada vez mais intensas demandas pela accountability governamental nos países industrializados. ${ }^{14}$

Nazaré Cabral destaca alguns fatos em especial, como a introdução e o desenvolvimento, nos Estados Unidos, do PPBS (Planning, Programming and Budgeting System), que

“significou, no dizer de muitos dos seus defensores, uma verdadeira 'revolução' no modo de conceber a orçamentação das despesas do Estado e a previsão orçamental,

12 Comission on Organization of Executive Branch of the Government. Budgeting and accounting, Washington, 1949, p. 8, apud BURKHEAD, Jesse. Orçamento público, p. 177.

13 Em texto publicado em 2007.

14 SHAH, Anwar; SHEN, Chunli. A primer on performance budgeting, p. 137. 
concebidas agora segundo uma perspectiva claramente racionalizadora e de acordo com a ideia de que no domínio das decisões políticas orçamentais também há lugar a uma racionalidade pura e compreensiva". ${ }^{15}$

Observa, contudo, que alguns autores têm uma visão um pouco diferente, como Allen Schick, segundo o qual o PPBS foi o primeiro sistema orçamentário organizado de forma a acolher as múltiplas funções do orçamento (controle, gestão e planejamento) que foram surgindo e se afirmando ao longo do tempo na história do direito orçamentário norte-americano. ${ }^{16}$

A síntese elaborada pela citada autora da evolução da reforma do sistema orçamentário norte-americano é extremamente esclarecedora, permitindo compreender os diversos modelos orçamentários surgidos, contextualizados nos momentos históricos. ${ }^{17}$ Primeiro, esclarece as três funções orçamentárias: ${ }^{18}$ a) função de controle, que permite verificar se as ações governamentais foram cumpridas de forma eficaz e eficiente; b) função de gestão, por meio da qual os administradores públicos podem aferir a eficiência e eficácia do uso dos recursos públicos, tendo em vista os objetivos da organização; e c) função de planejamento estratégico, pela qual se definem os objetivos do ente, as políticas públicas a serem implementadas e as alocações de recursos para cumpri-los. ${ }^{19}$

15 CABRAL, Nazaré da Costa. Programação e decisão orçamental. Da racionalidade das decisões orçamentais à racionalidade econômica, p. 379.

16 CABRAL, Nazaré da Costa. Programação e decisão orçamental. Da racionalidade das decisões orçamentais à racionalidade econômica, p. 379.

17 A análise efetuada pela autora tem como base, entre outros textos, o de Allen Schick, "The road to PPB: the stages of budget reform", a que tivemos acesso e consta nas referências; no entanto, dada a bem construída análise da autora, optamos por expor essa síntese com base em seu texto.

18 Conforme sistematização de Robert Anthony e Allen Schick.

19 CABRAL, Nazaré da Costa. Programação e decisão orçamental. Da racionalidade das decisões orçamentais à racionalidade econômica, p. 380. Em Allen Schick, The road to PPB: the stages of budget reform. In: LYDEN, Fremont J.; MILLER, Ernest G. Public budgeting: program planning and evaluation, p. 19: "Every budget system, even rudimentary ones, comprises planning, management, and control process. Operationally, these processes often are indivisible, but for analytic purposes they are distinguished here. (...) Planning involves the determination of objectives, the evaluation of alternative courses of action, and the authorization of selected programs. (...) Management involves the programming of approved goals into specific projects and activities, the design of organizational units to carry out approved programs and the staffing of these units and the procurement of necessary resources. (...) Control refers to the process of binding operating officials to the policies and plans set by their superiors. Control is predominant during the execution and audit stages, although the form of budget estimates and appropriations often is determined by control considerations". 
Essas funções possibilitam identificar três etapas na reforma do sistema orçamentário norte-americano ao longo do século XX.

A primeira fase, no período de 1920 a 1935, caracteriza-se pela perspectiva do controle, em que o orçamento continha rubricas orçamentais com dotações específicas e limitativas para a realização das despesas, de modo a tornar a peça orçamentária essencialmente um instrumento de controle da execução do gasto. ${ }^{20}$

A segunda fase, a partir da década de 1930, coincide com o período das políticas do New Deal, com forte ênfase no aspecto tributário e com foco na relação entre a despesa pública e o estado global da economia. Em 1949, com os trabalhos da Comissão Hoover, criou-se nova metodologia de organização dos orçamentos públicos. Além do aperfeiçoamento em aspectos do funcionamento da administração pública, estabeleceram-se modificações na forma de apresentação dos orçamentos, com destaque para a "nomenclatura" baseada em funções, atividades e programas da administração, fazendo referência ao performance budget. A perspectiva passa a ser de gestão, com o objetivo de ajudar os administradores públicos a aumentarem a eficiência na gestão, com a apresentação do orçamento em termos funcionais e com indicadores que permitam aferir o custo em relação às finalidades estabelecidas. Destaca-se, ainda nessa segunda etapa, a nova forma de apresentação dos orçamentos, sugerida pela 2a Comissão Hoover, em 1954, que é a de "orçamento de programas" (program budgeting), que passou a ser o elemento central do processo orçamentário no sistema PPB (Program, Planning and Budgeting), ${ }^{21}$ sendo acolhido na legislação brasileira até hoje vigente, conforme se constata dos arts. $2^{\circ}$, da Lei n. 4.320, de 1964, e 16, do Decreto-lei n. 200, de 1967.

$\mathrm{Na}$ terceira fase, ocorre a introdução do PPBS, voltando-se o orçamento para sua perspectiva de planejamento, com a política orçamentária sendo utilizada como instrumento de política econômica e havendo aperfeiçoamento das técnicas de modo a convergir o planejamento para a orçamentação. A orientação ou perspectiva planejadora, da qual o PPBS é expoente, evidencia uma nova concepção dos orçamentos, diferenciando-se das anteriores, por estabelecer uma relação indissociável entre os orçamentos públicos e a condução da política econômica. Destaca-se ainda no PPBS a sua dimensão de plurianualidade, bem como a introdução de novas práticas de gestão pública, com novas técnicas, metodologias e alteração de

20 Nesse sentido: SCHICK, Allen. The road to PPB: the stages of budget reform, p. 21.

21 CABRAL, Nazaré da Costa. Programação e decisão orçamental. Da racionalidade das decisões orçamentais à racionalidade econômica, p. 381; e SCHICK, Allen. The road to PPB: the stages of budget reform, p. 21. 
comportamentos e condutas da burocracia. Permitia ainda aos governantes terem uma visão mais ampla da organização e exercerem maior influência nas decisões, tomadas com base em informaçôes mais completas sobre custos e resultados, levando-os a conduzir com mais clareza as políticas públicas a serem implementadas. Com o PPBS, estabelecia-se uma ligação mais clara entre o orçamento e os grandes objetivos da política econômica, sendo utilizados critérios voltados a uma otimização dos recursos e que permitiam melhor controle e possibilidade de avaliar os resultados. ${ }^{22}$

No desenvolvimento dos vários modelos orçamentários, associados à gestão pública nos Estados Unidos na segunda metade do século XX, destacam-se, além do PPBS, outras que releva mencionar e que marcam a evolução das técnicas orçamentárias, que serão mais bem explicitadas à frente, adiantando-se por ora breve referência. Entre elas, estão: a gestão por objetivos (management by objectives $\mathrm{MBO})$, surgida no âmbito do setor privado, caracterizada por definição de estratégias no nível central e descentralização da implantação das ações; o orçamento base zero (zero-based budgeting), centrado na reavaliação de cada programa; e o TBB (target-based budgeting), baseado na definição das prioridades e no estabelecimento de limites de despesa pelos níveis mais altos da administração, deixando a escolha para os níveis inferiores (método top-down), descentralizando a decisão política e conferindo maior liberdade gerencial. ${ }^{23}$ Sousa Franco classifica-as como experiências de sistemas baseados na "eficiência gestionária", mencionando entre elas os orçamentos funcionais, os orçamentos por programas, o sistema de gestão por objetivos ( $\mathrm{MBO}$ - management by objectives), o orçamento base zero, o orçamento de tarefas (considerando como tal a técnica que "busca a justificação das despesas por actividades, justificadas e avaliadas por cada serviço ou unidade orgânica e selecionadas segundo critérios de eficiência") e o orçamento de resultados ou de desemprego (performance budget). ${ }^{24}$

Diversos fatores provocaram a adoção de novas técnicas orçamentárias para aperfeiçoar o desempenho do setor público, como bem registrado por Curristine: o crescimento das demandas por despesas; os serviços de maior qualidade; e, em alguns países, o crescimento da resistência dos contribuintes ao aumento da carga tributária. No âmbito dos governos, as estratégias para enfrentar esses desafios

22 CABRAL, Nazaré da Costa. Programação e decisão orçamental. Da racionalidade das decisões orçamentais à racionalidade econômica, p. 383-385.

23 Veja-se quadro (caixa 21) em CABRAL, Nazaré da Costa. A teoria do federalismo financeiro, p. 256-257.

24 FRANCO, Antonio L. de Sousa. Finanças públicas e direito financeiro, v. I, p. 422-423. 
envolveram a introdução de medidas de desempenho na orçamentação e na gestão, a flexibilização no controle dos inputs, ${ }^{25}$ a delegação de responsabilidades para órgãos governamentais e mudanças na relação entre o governo e os servidores públicos, com o avanço da terceirização e a introdução da remuneração ligada ao desempenho. ${ }^{26}$

José Luís Ruiz Álvarez e José Caamaño Alegre consideram possíveis causas da introdução do orçamento por desempenho a crise financeira dos anos 1990, a pressão para limitar o tamanho do Estado, as demandas dos cidadãos por maior qualidade nos serviços públicos e as mudanças de governo. Registram que a gestão baseada em desempenho trouxe uma série de benefícios, entre os quais ter gerado um aumento no governo pelo interesse em resultados, proporcionado maior informação sobre objetivos e prioridades do governo, incentivo ao planejamento plurianual, fortalecimento da transparência da ação governamental e consequente melhoria nas informações para os parlamentares, e o aperfeiçoamento da gestão dos programas e mensuração de seu nível de eficiência. ${ }^{27}$

Vale deter-se neste ponto em uma análise mais detalhada do que podemos denominar técnicas, metodologias, ou modelos, de orçamentação (entendida a expressão em uma concepção ampla), abrangidos na terminologia também os aspectos de planejamento e gestão a ela inerentes, e tentar clarear da melhor forma os conceitos aos quais já se fez referência anteriormente, ainda que, como se poderá constatar, não apresentem sempre uma nitidez que permita diferenciá-los com absoluta precisão.

\subsection{EVOLUÇÃO DAS TÉCNICAS ORÇAMENTÁRIAS | ALGUNS MODELOS CONSAGRADOS}

O aperfeiçoamento experimentado pelos sistemas orçamentários ao longo de sua evolução, que guarda estreita vinculação com o planejamento e a gestão, deu

25 Alguns termos técnicos são importantes, recorrentes e requerem melhor compreensão; contudo, para não interromper o fluxo do texto, esses termos foram inseridos no item 2.6 - "Excurso. Conceitos relevantes para a compreensão dos modelos e técnicas orçamentários" deste trabalho, em que são discutidos com maior profundidade.

26 CURRISTINE, Teresa. Government performance. Lessons and challenges. OECD Journal on Budgeting, p. 128. No texto original: "the introduction of performance measures into budgeting and management, the relaxation of input controls, the delegation of responsibility to line ministries/agencies, and changes in public employment typified by the adoption of contracts for public servants and the introduction of performance-related pay".

27 ÁLVAREZ; José Luís Ruiz; ALEGRE, José Caamaño. Tendencias en la gestión presupuestaria a nivel internacional. Presupuesto y Gasto Público 51/2008, p. 32. 
origem a várias denominações de técnicas e modelos orçamentários, aos quais já se fez referência anteriormente, sendo adequado e conveniente uma explicitação individualizada de cada um, permitindo melhor compreendê-los.

\subsubsection{O orçamento "clássico" ou "tradicional"}

O que hoje se denomina orçamento "clássico", ou "tradicional", na precisa síntese de José Afonso da Silva, é aquele

"cuja origem se identifica com a das instituiçōes democráticas representativas, era uma peça de previsão das receitas e autorização das despesas públicas, classificadas estas por objeto, sem se cogitar das necessidades reais da administração e da população, nem dos objetivos econômico-sociais a atingir com sua execução". ${ }^{28}$

Tem como características básicas a classificação das despesas por itens, ou "por linhas" (line-item budget), com ênfase nos inputs, ou seja, nos insumos ou itens de gasto, fornecendo informações sobre como e quanto de recursos são gastos, em vez de especificar no que são aplicados, sem estabelecer vínculo entre os inputs e os outputs, o que acaba por não permitir aferir a eficiência do gasto. ${ }^{29}$

\subsubsection{O orçamento funcional}

José Afonso da Silva registra o "orçamento funcional" como o primeiro passo nas reformas das técnicas orçamentárias, em que se deixa de tratar o orçamento como mero documento de registro e controle de despesas para reconhecê-lo como instrumento de intervenção do estado na economia, criado para aperfeiçoar e dar maior eficiência ao serviço público. Nas propostas da Comissão Taft, conforme registra o autor, recomendaram-se avaliar e autorizar as despesas por funçôes, de modo que as dotações fossem focadas no objetivo, na finalidade do gasto público. ${ }^{30}$ Tem por característica marcante a classificação das despesas por " funções, atividades e tarefas governamentais (educação, saúde, tantas crianças a alfabetizar, tantos doentes a atender) e não por objeto (pessoal, material, serviços de terceiros etc.) como no orçamento tradicional".31

É a primeira tentativa de superar as limitações do orçamento clássico, como registra Pascual García, em que a técnica de agrupar as despesas nas grandes funções

\footnotetext{
SILVA, José Afonso da. Orçamento-programa no Brasil, p. 1.

29 SHAH, Anwar; SHEN, Chunli. A primer on performance budgeting, p. 139.

30 SILVA, José Afonso da. Orçamento-programa no Brasil, p. 14-15.

31 SILVA, José Afonso da. Orçamento-programa no Brasil, p. 15.
} 
do Estado de modo a detalhar o destino dos gastos públicos tem a virtude de informar o cidadão sobre a quantidade e a qualidade das funções públicas. ${ }^{32}$

\subsubsection{Orçamento-programa}

A ideia de "orçamento-programa" surge a partir do reconhecimento da função do orçamento como "instrumento de programação econômica, de programação da ação governamental”, representando uma técnica que faz dele "um tipo de orçamento vinculado ao planejamento das atividades governamentais", um "instrumento de execução de planos e projetos de realização de obras e serviços, visando ao desenvolvimento da comunidade". ${ }^{33} \mathrm{O}$ orçamento-programa, nas precisas e esclarecedoras palavras de José Afonso da Silva, e que demonstram de forma bastante clara o papel fundamental que o orçamento passa a ter como vínculo entre o planejamento econômico governamental e a efetivação da despesa pública,

"é o equivalente financeiro do plano de ação governamental. Nunca pode ser independente do plano. Mostra de onde vêm os recursos para financiar o plano e quanto deve ser gasto para atingir os objetivos traçados. Distribui os recursos às diferentes atividades e projetos. Indica: a) que projetos e que atividades devem ser empreendidos; b) qual a magnitude dêsses projetos e atividades; c) onde e quando deverão ser empreendidos. Reserva-se o têrmo orçamento-programa para designar essa técnica orçamentária que vincula orçamento e planejamento, considerado aquêle como uma etapa do processo de planificação econômica e social". ${ }^{34}$

O orçamento-programa tem como característica fundamental vincular as despesas aos resultados, expressos em unidades físicas. ${ }^{35}$ Programa-se para:

"atingir objetivos claramente definidos, atender necessidades rigorosamente diagnosticadas, segundo uma ordem de prioridade estabelecida à vista das metas traçadas no Plano de Desenvolvimento e após eleger a melhor alternativa das que se oferecem ao programador. Enfim, clarificação de objetivos, formulação das estruturas de programa-atividade e análise de custo-benefício são os três passos do processo de análise que devem preceder e continuar a apoiar a implementação do orçamento-programa. Fora disso, poder-se-á ter orçamento por programas, mas não orçamento-programa, que exige, além disso, vinculação com o processo de planejamento". ${ }^{36}$

32 ATCHABAHIAN, Adolfo. Régimen jurídico de la gestión y del control en la hacienda pública, p. 262.

33 SILVA, José Afonso da. Orçamento-programa no Brasil, p. 41.

34 SILVA, José Afonso da. Orçamento-programa no Brasil, p. 42.

35 SILVA, José Afonso da. Orçamento-programa no Brasil, p. 63.

36 SILVA, José Afonso da. Orçamento-programa no Brasil, p. 64. 
E destaca o mesmo autor o papel do orçamento-programa no âmbito do planejamento, em texto recente: "reserva-se o termo orçamento-programa para designar essa técnica orçamentária que vincula orçamento e planejamento, considerado aquele como uma etapa do processo de planificação econômica e social". ${ }^{37}$

O programa é, ainda hoje, no sistema de planejamento orçamentário brasileiro, a peça fundamental na vinculação entre o plano e o orçamento, bem como no estabelecimento de um novo papel para o gestor público, que passa a se comprometer com os resultados de sua ação para a sociedade, como bem destacado por Ariel Pares e Beatrice Valle:

"No atual modelo de planejamento, a unidade comum de integração entre o plano e o orçamento, o programa, é também uma unidade nova de organização de meios públicos voltados para o resultado na sociedade. O programa como unidade de gestão contribui para a transformação da gestão das organizaçôes públicas. A combinação do programa, unidade de resultados, às formas tradicionais de organização administrativa, unidade com missão e função, possibilita a modernização do Estado na direção de uma gestão matricial simultaneamente por resultados e por função e missão. Esse movimento de integração entre o programa e as organizaçóes iniciou-se com o PPA 2004-2007. O gerente de programa passa a ser o mesmo gestor público das organizaçôes, levando-as a um compromisso não só com o gasto, mas também com os resultados desse gasto na sociedade, ou seja, as organizaçōes orientam a otimização de processos e a qualidade das funçōes para a produção de bens e serviços inteiramente alinhados com a obtenção de resultados. Na figura do gestor público, responsável ao mesmo tempo pelo programa e pela unidade administrativa, é que se articulam essas duas figuras da gestão pública. Assim como o programa exerce a função de integrar plano e orçamento, o gerente de programa possibilita a integração programa e organização". ${ }^{38}$

E a existência de um gerente responsável permite "o exercício da matricialidade do plano, pois, a despeito da estrutura hierárquica organizacional, o gerente poderia atuar no sentido de articular os meios para o enfrentamento dos problemas dos quais derivavam os programas, transpassando a fronteira da organização à qual pertencia funcionalmente". ${ }^{39}$

Do exposto, pode-se inferir que o conceito de orçamento-programa corresponde a uma técnica de orçamentação que se constitui em um instrumento por

SILVA, José Afonso da. Orçamento-programa no Brasil, p. 104.

38 PARES, Ariel; VALLE, Beatrice. A retomada do planejamento governamental no Brasil e seus desafios. In: GIACOMONI, James; PAGNUSSAT, José Luiz (Org.). Planejamento e orçamento governamental, p. 241.

39 PARES, Ariel; VALLE, Beatrice. A retomada do planejamento governamental no Brasil e seus desafios, p. 246. 
meio do qual o planejamento governamental se materializa em dotações orçamentárias precisas e específicas, na forma de programas, que definem atividades e projetos com resultados e metas, de modo a vincular as referidas dotações ao atingimento dos objetivos fixados no plano.

\subsubsection{Orçamento por resultados}

A concepção de orçamento por resultados (Results-Based Budgeting - RBB) visa a transformar a ideia de orçamento tradicional, focado nos inputs, para direcionar as despesas, classificando-as nas peças orçamentárias, de modo a vinculá-las aos resultados pretendidos com as ações governamentais para as quais foram consignadas dotações. Uma forma de fazer com que os aplicadores dos recursos os utilizem para atingir determinados resultados, conforme nos esclarece Regis de Oliveira. ${ }^{40}$

Insere-se no âmbito do orçamento como peça integrada ao sistema de planejamento e à gestão pública, representando aspecto das demais técnicas orçamentárias que se inserem nesse processo de modernização da administração e orçamentação públicas.

Tal como as demais modalidades, a conceituação de orçamento por resultados não é fácil, não havendo concordância sobre uma exata definição. A Secretaria-Geral das Nações Unidas utiliza-se da definição segundo a qual o orçamento por resultados é uma modalidade de orçamento por programas em que: a) a formulação dos programas gira em torno de um conjunto de objetivos predefinidos e resultados esperados; b) os resultados esperados justificam a demanda de recursos, que são vinculados aos produtos necessários para atingir esses resultados; e c) o desempenho efetivo no alcance dos resultados é medido por indicadores objetivos de desempenho. ${ }^{41}$

40 OLIVEIRA, Regis F. Orçamento de resultado ou de desempenho. Revista Fórum de Direito Financeiro e Econômico, p. 17: "O orçamento de resultado tem sido definido como um sistema no qual os aplicadores providenciam com certa flexibilidade e utilização dos recursos para atingir determinados resultados. $\mathrm{O}$ que se espera é que o aplicador dos recursos use-os no perfil de obrigações de programas dentro de certos parâmetros".

41 ABRASZEWSKI, Andrzej T.; BOUAYAD-AGHA, Fatih; FOX, John D.; MÜNCH, Wolfgang. Results-based budgeting: the experience of United States system organizations, p. 3. No original: "For the purpose of this report, it seems appropriate to use the definition of RBB offered by the Secretary-General of the United Nations: A programme budget process in which: (a) programme formulation revolves around a set of predefined objectives and expected results; (b) expected results justify the resource requirements which are derived from and linked to outputs required to achieve such results; and (c) actual performance 
O orçamento por resultados, conforme explicita Rodrigo Faria em texto dedicado ao tema:

"encontra-se inserido no contexto mais amplo da Gestão por Resultados, por meio da qual se procura melhorar o desempenho do poder público, incorporando critérios de eficiência, de eficácia e de efetividade na realização de suas atividades. Em outros termos, pretende-se deslocar o eixo de orientação estatal, predominantemente voltado para meios e insumos (inputs), com vistas a se conferir ênfase aos produtos e serviços entregues (outputs), bem como aos resultados derivados da atuação estatal (outcomes)" ${ }^{42}$

Segue na mesma direção da ideia de orçamento de desempenho (performance budget), sobre o qual se falará mais detidamente a seguir, procurando abranger a concepção de desempenho e de resultados ao processo orçamentário:

"Orçamento por Resultados e Orçamento de Desempenho (performance budgeting) são nomenclaturas diferentes que procuram exprimir a mesma ideia central, qual seja, a integração de informaçôes sobre desempenho e resultados ao processo orçamentário e sua utilização no processo de tomada de decisão. Referido entendimento também é defendido pela OCDE: 'A variety of terms and definitions are incorporated under the label of performance budgeting: budgeting for results, performance-based budgeting and performance funding. These terms are all concerned with introducing performance information into budget processes' (OECD, Performance Budgeting in OECD Countries, 2007, p. 20)" ${ }^{43}$

Trata-se de modalidade de orçamentação relevante para o planejamento e a gestão, na medida em que propicia a utilização das informações sobre os resultados no processo de decisão acerca da alocação dos recursos públicos: "A tônica, pois, das diversas modalidades de Orçamento por Resultado se assenta sobre a utilização da informação sobre resultados no processo decisório". ${ }^{4}$

in achieving results is measured by objective performance indicators"), ou, em versão resumida e adaptada, é um modelo de orçamento por programas baseado em uma quantidade de resultados desejados, previstos quando da elaboração do orçamento, em que o desempenho é medido ao final do período (no original: "RBB is about formulating programme budgets that are driven by a number of desired results which are articulated at the outset of the budgetary process, and against which actual performance is measured at the end of a biennium".

42 FARIA, Rodrigo Oliveira de. Orçamento por resultados: tendências, perspectivas e desafios. BRASIL. Ministério do Planejamento, Orçamento e Gestão. Secretaria de Orçamento Federal. Orçamento público, p. 336.

43 FARIA, Rodrigo Oliveira de. Orçamento por resultados: tendências, perspectivas e desafios, p. 338, nota de rodapé 6 .

44 FARIA, Rodrigo Oliveira de. Orçamento por resultados: tendências, perspectivas e desafios, p. 338-339. 
É relevante destacar, nesse ponto, a menção feita pelo autor à classificação tripartite desenhada pela OCDE, conforme o grau de utilização da informação de performance na tomada de decisão:

“i) Orçamento por Resultados Aparente ou Demonstrativo - OpRA (Presentational performance budgeting): nessa modalidade, indicadores de desempenho acompanham a peça orçamentária ou outros documentos orçamentários, mas não cumprem nenhuma função na tomada de decisão alocativa;

ii) Orçamento por Resultados de alocação indireta - OpRAI (Performance informed budgeting): nesta versão os resultados são ativa e sistematicamente utilizados - embora de maneira indireta - para informar as decisóes orçamentárias. Em outras palavras: a informação sobre desempenho se constitui em relevante elemento constitutivo do processo de tomada de decisão - embora não determine o montante de recursos alocados - ao lado de outras informaçôes sobre prioridades políticas e fiscais.

iii) Orçamento por Resultados de alocação direta ou automática - OpRAD (Direct/formula performance budgeting): nessa categoria, o processo alocativo é diretamente dependente dos resultados e desempenho obtidos. Cada incremento alocativo se vincula expressamente a um incremento dos produtos/serviços ou dos resultados. As dotaçōes orçamentárias, nesse caso, podem estar baseadas em fórmulas e/ou contratos firmados, com indicadores específicos de desempenho. Tal modalidade requer indicações claras e explícitas de produtos e informação sobre custos unitários, que não se encontram disponíveis em diversos setores governamentais". ${ }^{45}$

Não obstante a já anunciada dificuldade em estabelecer com precisão esses conceitos, bem como diferenciá-los das outras técnicas e/ou modelos, o que se pode inferir é a ideia central que o fundamenta, a qual, no caso do orçamento por resultados, é a de que o orçamento é baseado em programas em que os recursos são alocados de forma a se vincularem a resultados que permitam a mensuração do desempenho.

O Estado de São Paulo implantou formalmente a metodologia de orçamento por resultados. O Decreto n. 57.598, de 2012, instituiu a "Comissão de Supervisão para a implantação do Orçamento por Resultados”, que orientou a produção do PPA 2016-2019 (conforme determinado pelo Decreto n. 61.174, de 2015 ${ }^{46}$ ), conforme expressa o referido documento. ${ }^{47}$

45 FARIA, Rodrigo Oliveira de. Orçamento por resultados: tendências, perspectivas e desafios, p. 339.

46 “Art. $3^{\circ}, \S 2^{\circ}$ A metodologia para elaboração, monitoramento da execução e avaliação de Programas e Açôes é a do Orçamento por Resultados, de acordo com o previsto no Decreto n. 57.958, de 5 de abril de 2012."

47 BRASIL. Governo do Estado de São Paulo. Plano Plurianual 2016-2019, v. I, p. 13. 
Nele, explicita a metodologia adotada, cuja principal inovação consiste na "especificação clara do que deve ser feito para chegar aos resultados almejados, destacando os vínculos causais entre os diversos níveis da atuação governamental”, o que exige um adequado desenho dos programas com seus produtos e açôes e uma correta "escolha dos indicadores adequados para medir e acompanhar os diferentes níveis de resultados do PPA". O desenho do programa com base na metodologia do Orçamento por Resultados implantado pelo Estado de São Paulo "significa responder às seguintes questôes: 1 . Aonde se quer chegar? Ou seja, qual o resultado pretendido pelo programa? Ele contribui para qual Objetivo Estratégico e como o faz? 2. Como chegar lá? Isto é, qual a intervenção, ou conjunto de produtos e ações, deve ser realizada pelo programa para que atinja o resultado almejado?”. Pretende-se, assim, construir um sistema logicamente encadeado, em que se estabelecem os objetivos estratégicos do governo, suas diretrizes, de modo que os programas formulados devem prever resultados que "deverão contribuir para as mudanças que se espera lograr na sociedade, expressas naqueles Objetivos”, de modo que a formulação do programa importa em "definir e quantificar os bens e serviços que ele pretende gerar por meio de suas ações, isto é, dos processos que transformarão os insumos utilizados (recursos públicos) naqueles produtos a serem entregues a seu público-alvo", de modo que "na concepção de cada programa governamental existe um encadeamento lógico-causal entre os insumos que mobiliza, os produtos que gera, os resultados que provoca e os impactos esperados na sociedade". 48

É de se destacar que a preocupação com os resultados segue a linha em que caminham os modernos sistemas de gestão, que devem vir acompanhados dos sistemas de planejamento orçamentário, estando intrinsecamente ligados à busca da melhoria na qualidade do gasto público. ${ }^{49}$

A adoção formal pelo Estado de São Paulo demonstra a importância que a técnica apresenta para o sistema de gestão e de planejamento orçamentário da administração

48 BRASIL. Governo do Estado de São Paulo. Plano Plurianual 2016-2019, v. I, p. 13. Veja-se também: BRASIL. Estado de São Paulo. Secretaria de Planejamento e Gestão. Orçamento por resultados no Estado de São Paulo: experiências, desafios e perspectivas.

49 Juan Camilo Restrepo, ao discorrer sobre as novas tendências em matéria orçamentária, exemplificando com o caso da Colômbia, registra: "La otra tendencia de pensamiento actual gira en torno a que la gestión presupuestal debe ser útil para evaluar la calidad del gasto público. ¿Qué eficiencia, realmente, con relación a los propósitos buscados, ha tenido el gasto público en determinado programa? Tal es la pregunta relacionada con la eficiencia del gasto que frecuentemente se hace la opinión pública. No es bueno que el gasto se repita año tras año de manera inercial, sin que se haga una verdadera evaluación de sus resultados" (Hacienda pública, p. 355). 
pública moderna, em que a forma de construção das leis que integram o sistema exige foco nos resultados, deixando definitivamente no passado o orçamento clássico ou tradicional.

\subsubsection{Performance budget: o orçamento de desempenho}

O "orçamento de desempenho"50 - o performance budget -, foi sugerido, como já mencionado, na primeira Comissão Hoover (Commission on Organization of the Executive Branch of the Government), como Recomendação n. 1 de seu Relatório sobre Orçamento e Contabilidade, propondo-se a remodelação da concepção orçamentária do governo federal norte-americano "pela adoção de um orçamento baseado em funçôes, atividades e projetos, e isso é o que se designou orçamento de desempenho (Performance Budget)".51

Trata-se de uma técnica que dá ênfase aos objetivos fixados para cada programa e às formas de mensurá-los, de modo que se possam avaliar os custos e resultados e, por consequência, o desempenho da administração em cada programa.

O orçamento de desempenho "é aquele que apresenta os propósitos e objetivos para os quais os créditos se fazem necessários, os custos dos programas propostos para atingir aqueles objetivos e dados quantitativos que meçam as realizações e o trabalho levado a efeito em cada programa", segundo a definição dada por Jesse Burkhead. ${ }^{52}$ Representa o conjunto de mecanismos por meio dos quais os recursos públicos se vinculam a resultados, pelo uso de informações de desempenho, com a finalidade de melhorar a eficiência do gasto público, como expõe Marc Robinson, em obra de referência no tema. ${ }^{53}$

Vê-se que as técnicas orçamentárias do orçamento-programa, do orçamento de resultados e o de desempenho têm propósitos semelhantes, aparecendo as diferenças entre elas basicamente nos enfoques que cada uma dá a aspectos da orçamentação, de modo a não ser possível estabelecer com segurança que sejam espécies ou categorias diversas de técnicas de orçamentação.

50 Ou de realização, conforme José Afonso da Silva. Orçamento-programa no Brasil, p. 18.

51 SILVA, José Afonso da. Orçamento-programa no Brasil, p. 18.

52 SILVA, José Afonso da. Orçamento-programa no Brasil, p. 18.

53 "The definition of performance budgeting put forward is a broad one. It refers to public sector funding mechanisms and processes designed to strengthen the linkage between funding and results (outputs and outcomes), through the systematic use of formal performance information, with the objective of improving the allocative and technical efficiency of public expenditure" (ROBINSON, Marc (Ed.). Performance budgeting. Linking funding and results, p. 1). 
Jesse Burkhead trata bem do tema, evidenciando não ser simples a distinção entre as denominações, mas passível de ser estabelecida:

"Não existe uma definição precisa para o orçamento de desempenho, pois veio a ter significados diferentes em cada jurisdição que o tenha adotado. Tem havido tendência para considerar-se (sic) sinônimas as expressóes orçamento-programa e orçamento de desempenho, o que tem levado a certa confusão de terminologia. Numa tentativa para esclarecer o que se pretendeu aqui designar por programa e desempenho, as definiçôes serão apresentadas em função da organização e hierarquia. Para os objetivos presentes, o programa será definido em relação a um nível mais elevado de organização do que desempenho. Um programa compreende várias unidades de desempenho. Um Departamento ou órgão pode levar a efeito vários programas diferentes ou deles participar, ao passo que as unidades organizacionais (de desempenho), situadas abaixo do nível de Bureau ou divisão dentro de um Departamento, desenvolvem atividades derivadas, sendo diretamente responsáveis pelo desempenho. Os custos do programa podem ser determinados pela soma dos custos das unidades de desempenho, constituindo tabelas-resumo. Por outro lado, um orçamento-programa pode limitar-se a custos em têrmos gerais; não há necessidade de estendê-lo à unidade de desempenho, detalhe que em alguns casos não possui utilidade alguma. Programa e desempenho podem também ser distinguidos segundo a dimensão tempo. Os programas orçamentários são, pela própria natureza, projeçōes para o futuro das políticas econômicas e sociais de um Govêrno. O desempenho deve ser baseado no passado, no registro das realizaçōes anteriores. (...) De acôrdo com essas definiçōes, um orçamento-programa atende a um objetivo diverso daquele do orçamento de desempenho. $\mathrm{O}$ orçamento-programa é útil para a revisão e tomada de decisōes no nível departamental ou superior. Adapta-se aos requisitos do planejamento orçamentário geral: à revisão pelo órgão central de orçamento, pelo chefe do Executivo e pelo Legislativo. O orçamento de desempenho pode também proporcionar informação útil para a revisão, mas além disso deve servir aos fins de administração, tanto no nível de departamento como abaixo. A classificação e a análise do desempenho procuram medir o custo e a realização das atividades discriminadas e, assim fazendo, melhorar a implementação dos programas". ${ }^{54}$

O orçamento de desempenho funda-se no correto registro das despesas no orçamento com base na classificação por desempenho, que é uma "técnica específica de organizar e apresentar dados do orçamento para unidades administrativas compreendidas nos departamentos ou órgãos”. Na classificação por desempenho, os bens adquiridos pelo governo não devem ser classificados apenas pelo tipo, mas reunidos e organizados conforme as atividades a que servem; devem ser vistos como elementos dessas atividades. Importa o produto, o resultado que se espera obter com os bens adquiridos. Exemplifica o autor que, em uma classificação por desempenho,

54 BURKHEAD, Jesse. Orçamento público, p. 182-183. 
"uma tonelada de cimento é potencialmente um trecho de estrada, uma reprêsa ou um edifício de concreto, e assim classificada. A ênfase está no processo, no objetivo ou na realização. Uma tonelada de cimento, combinada com outros materiais, algum equipamento e atividades físicas de trabalhadores torna-se um produto final específico para a implementação das decisões do programa".

E finaliza: "a classificação de desempenho representa o elo entre as coisas adquiridas e as coisas feitas ou tarefas realizadas". 55

Há diversas dificuldades para desenvolver e aplicar essas técnicas de orçamento por performance, como registrado por Curristine. A quantidade de informações sobre desempenho disponíveis para os tomadores de decisão cresceu significativamente; contudo, os países continuam a ter dificuldades em relação à qualidade das informações e em garantir que sejam utilizadas. Estabelecer medidas de desempenho e indicadores confiáveis e bem construídos é tarefa demorada e complexa, como também o é mudar o comportamento dos agentes envolvidos, políticos ou burocratas, de modo a fazê-los usar essas informaçôes para desenvolver a cultura da performance compatível com seus respectivos órgãos ou setores da administração. Mas é um processo que veio para ficar, assegura com convicção, ${ }^{56}$ enquanto Allen Schick o vê mais como uma esperança para o futuro: "performance budgeting is an idea whose time will come" ${ }^{57} \mathrm{E}$ ressalta que o difícil é implementá-lo, considerando essa técnica, em seu modo de ver, simples de explicar, consistindo basicamente na ideia de que os governos devem orçar os resultados esperados, em termos de outputs e outcomes, em vez dos insumos (inputs). ${ }^{58}$ Ao mesmo tempo, o autor admite ser uma técnica que apresenta tantas variações quanto são diversificados os governos que tentaram implementá-la. ${ }^{59}$ Essas dificuldades de implementação da

55 BURKHEAD, Jesse. Orçamento público, p. 184.

56 CURRISTINE, Teresa. Government performance. Lessons and challenges, p. 128.

57 SCHICK, Allen. Does budgeting have a future? p. 43.

58 "Performance budgeting is easy to explain but has been hard to implement. The basic idea is that governments should budget for actual or expected results (typically labelled as outputs and outcomes) rather than for inputs (personnel, supplies and other items). When deciding the budget, governments should be informed of the services that public agencies will provide and the expected benefits and social conditions that will derive from spending public funds. As appealing and sensible as this idea is, putting it into practice has been exceedingly difficult. Governments have many things on their minds when they allocate resources; performance is only one preoccupation and usually not the most urgent" (SCHICK, Allen. Performance budgeting and accrual budgeting: decision rules or analytics tools? OECD Journal on Budgeting, p. 122).

59 SCHICK, Allen. Performance budgeting and accrual budgeting: decision rules or analytics tools? p. 123 . 
técnica já eram mencionadas por Jesse Burkhead, como destaca ao evidenciar o problema diante da complexidade da administração pública e até mesmo da multissetorialidade dos programas: ${ }^{60}$

"Em todo Govêrno, um certo número de programas é executado por duas ou mais unidades administrativas em conjunto. Isto significa que a responsabilidade administrativa é dividida e as linhas hierárquicas de autoridade não ficam claramente definidas. Nem as atividades nem os produtos finais específicos podem ser atribuídos a uma única organização, e a responsabilidade pelo desempenho não pode ser prontamente determinada. Em outros casos, apenas uma unidade administrativa executará certo número de diferentes programas. Neste caso, o cálculo do custo se torna difícil e requer a distribuição do tempo dos servidores, através do uso de fôlhas de registro ou outra forma de anotação quando o pormenor se fizer necessário". ${ }^{61}$

Premchand, em outra obra em que faz leitura indispensável neste tema, também reconhece a similaridade dos conceitos de Program Budgeting e Performance Budgeting, bem como a dificuldade em diferenciá-los, ${ }^{62}$ procurando explicitá-los de modo a permitir melhor compreendê-los.

Informa que as técnicas de performance budgeting, que estavam sendo utilizadas em alguns entes da federação norte-americana e órgãos governamentais, foram recomendadas pela Comissão Hoover para aplicação no governo federal (como já mencionado anteriormente). Destaca os três elementos que compõem o performance budget previsto pela referida Comissão: a) classificações das operações governamentais em programas; b) critérios de mensuração de desempenho; e c) relatórios de desempenho. Há grande preocupação com a contabilização dos custos envolvidos e a eficácia dos resultados obtidos, permitindo relacionar os objetivos alcançados com as despesas necessárias para tanto. O performance budget é estruturado em programas dotados de indicadores de produtividade, informações sobre a carga de trabalho, objetivos pretendidos, com metas e resultados. ${ }^{63}$

O autor observa que a Comissão Hoover considerava as duas expressões “intercambiáveis", mas preferia usar o termo Program Budget. O orçamento-programa dá ênfase aos aspectos de classificação orçamentária das despesas em que os custos possam ser considerados ao longo de um período, de modo a considerar o desem-

60 O que, como se verá, não são dificuldades exclusivas desta técnica, mas também atingem outras da mesma natureza.

61 BURKHEAD, Jesse. Orçamento público, p. 192.

62 "A question that has not so far been resolved satisfactorily is the basic difference between performance and program budgeting" (PREMCHAND, A. Government budgeting and expenditure. Theory and practice, p. 323).

63 PREMCHAND, A. Government budgeting and expenditure. Theory and practice, p. 321-322. 
penho das atividades governamentais em um prazo mais longo. O orçamento-programa, dessa forma, diferencia-se do orçamento de desempenho por dar mais ênfase às classificações orçamentárias e ter uma maior visão de futuro, portanto mais voltado ao planejamento. $\mathrm{O}$ orçamento de desempenho volta-se mais para a questão do controle e do gerenciamento, enquanto o orçamento-programa direciona-se ao planejamento, ${ }^{64}$ aspecto também destacado claramente por Allen Schick. ${ }^{65}$

Em sentido semelhante, encontramos a posição de Nazaré Cabral:

"Por causa da proximidade conceptual, as expressões Performance Budgeting e Program Budgeting foram vulgarmente confundidas, aspecto que viria a merecer crítica de alguns autores e tentativas de delimitação conceptual, por parte de outros. É, de novo em Schick, que encontramos uma tentativa aprofundada de estabelecer essa delimitação. E a diferença não se prende só com o hiato temporal que mediou entre o aparecimento do Performance Budgeting e do Program Budgeting. Na verdade, a distinção é de natureza substantiva. Ao contrário do Performance Budgeting, que é instrumento de gestão, o Program Budgeting obedece a uma perspectiva de planeamento, sendo certo que o seu maior objectivo é o da racionalização da decisão, ao assegurar: i) o fornecimento de dados sobre custos e benefícios referentes às diversas alternativas capazes de atingir as metas definidas; ii) a existência de indicadores de resultado que facilitam a concretização desses mesmos objectivos. Assim, enquanto o primeiro retira o seu ethos e grande parte da sua técnica da contabilidade de custos e da gestão científica, o segundo retira as suas ideias-chave da economia e da análise de sistemas. Na literatura especializada sobre Performance Budgeting, a orçamentação é vista como um instrumento de gestão e o orçamento um 'programa de trabalho'; já na que se refere ao Program Budgeting, a orçamentação é entendida como um processo de afectação de recursos e o orçamento contém claramente uma afirmação de política económica. Na verdade, a ideia central do primeiro é a de que o processo orçamental esteja focalizado em programas e funções - ou seja, naquilo que tem de ser alcançado, no trabalho que tem de ser realizado. Diversamente, a ideia do segundo não é tanto a do trabalho que deve ser concretizado pelos serviços, antes, numa perspectiva macro, os objectivos a alcançar pela aplicação dos dinheiros públicos. Assim sendo, enquanto naquele o trabalho e as actividades são entendidas como fins em si mesmos, neste o trabalho e os serviços são concebidos como aspectos intermediários, no processo de reconversão dos recursos em resultados. Concomitantemente, os objectivos da avaliação também divergem num caso e no outro, pelo que reclamam diferentes métodos de classificação, no primeiro uma classificação (das despesas) por actividades, no segundo uma classificação 'de produto final' ou 'de resultado'”. ${ }^{66}$

64 PREMCHAND, A. Government budgeting and expenditure. Theory and practice, p. 323-324.

65 "Performance budgeting is management-oriented; program budgeting (PPB) is planning-oriented" (SCHICK, Allen. The road to PPB: the stages of budget reform, p. 29).

66 CABRAL, Nazaré da Costa. Programação e decisão orçamental. Da racionalidade das decisões orçamentais à racionalidade económica, p. 382. 
Para Anwar Shah, o performance budget é um sistema de orçamentação que mostra os objetivos para os quais os recursos são destinados, os custos dos programas voltados a atingir esses objetivos e os produtos e resultados que se esperam alcançar em cada programa. ${ }^{67}$

No caso do performance budget, a inter-relação dessa técnica orçamentária com as técnicas de gestão com funções correlatas (performance management) tornam ainda mais complexas e sutis uma distinção e conceituação mais precisas. A gestão por desempenho - performance management - é a administração voltada a resultados, com destaque para as informações de desempenho, avaliação, monitoramento e relatórios de performance. O performance budget, orçamentação baseada em resultados, conforme bem acentuado por Curristine, está sujeito a várias interpretações, desde aquele que o define como o que mostra informações sobre o que se fez com os recursos ou o que se espera fazer com ele, caso em que as informaçóes de desempenho são apenas parte da peça orçamentária, ou aquele em que a classificação das dotações são estabelecidas por grupos de outpus ou outcomes. A definição de performance based budgeting, contudo, sempre representa uma técnica orçamentária que relaciona os recursos com resultados mensuráveis, direta ou indiretamente, na forma de outpus ou outcomes. ${ }^{68}$

No Brasil, a preocupação com o planejamento orçamentário governamental baseado em resultados ficou evidenciada no PPA federal 2000-2003, ${ }^{69}$ no qual ficou mais clara a integração plano-orçamento, com incentivo ao gestor para focar nos resultados e no desempenho. Toda a ação finalística do Governo passou a ser estruturada em programas, orientados para a consecução dos objetivos estratégicos definidos para o período do Plano (Decreto n. 2.829, de 1998, art. 1º), devendo cada programa conter, além do objetivo, órgão responsável, valor global, prazo de conclusão e fonte de financiamento, o indicador que quantifique a situação que o programa tenha por fim modificar e as metas correspondentes aos bens e serviços necessários para atingir o objetivo (art. $2^{\circ}$ ), com a designação de profissional capacitado para ser o gerente do Programa (art. 4o), submetendo-se os Programas a avaliações periódicas físicas e financeiras com a finalidade de aferir o resultado (art. 6o). E a diretriz governamental foi bem clara ao asseverar que a "administração pública deve estar preocupada com custos e resultados. Deve melhorar a eficiência e a eficácia do gasto público, aperfeiçoando os próprios instrumentos de

SHAH, Anwar; SHEN, Chunli. A primer on performance budgeting, p. 143.

68 CURRISTINE, Teresa. Government performance. Lessons and challenges, p. 131.

69 Tema que será abordado de forma mais específica e detalhada em tópico próprio (item 3.4.2.3). 
gestão - o Plano Plurianual e os Orçamentos da União. Com isso, será possível conciliar crescimento com equilíbrio confiável das contas do Estado" ${ }^{70}$

A mensuração do desempenho, e a adoção de técnica que permita mensurá-lo, além de estar em consonância com o avanço que se espera em matéria de planejamento orçamentário, para o que se mostra de grande relevância, é especialmente importante para o aumento da qualidade do gasto, atual preocupação vigente em matéria de administração dos recursos públicos, inclusive usada como denominação de projetos voltados a substituir a Lei n. 4.320, de 1964.

\subsubsection{PPBS (Planning, Programming and Budgeting System)}

O aperfeiçoamento do Program Budgeting, ao ser implementado no Departamento de Defesa norte-americano, sob comando do Secretário de Defesa Robert McNamara, em 1965, deu origem ao PPBS (Planning, Programming and Budgeting System). Baseado nos modelos dos outros sistemas, conforme relata Premchand, diferencia-se deles ao oferecer uma abordagem paradigmática para a formulação de políticas públicas envolvendo a especificação de objetivos, formulação de programas, uma análise crítica das alternativas, avaliações de longo prazo e aplicação de técnicas quantitativas. O PPBS formulado pelo governo envolvia basicamente três níveis de gestão: a) gestão de políticas, com a identificação das necessidades, análise de opções, seleção de programas e alocação de recursos; b) gestão de recursos, com a criação e o aperfeiçoamento das estruturas de apoio e garantias orçamentárias e novas práticas de gestão financeira; e c) gestão de programas, com a implementação de políticas públicas, novas práticas contábeis, de avaliação, informaçãao e transparência. ${ }^{71}$ Vê-se uma diferença de abordagem e na forma de organização e apresentação.

O sistema PPBS, esclarece Sousa Franco, comporta três fases:

"a) o planning, que consiste na definição de objetivos da acção governamental respectiva no horizonte de 20 anos; b) o programming, que comporta a análise dos programas e a definição dos meios aptos a prosseguir esses objectivos a médio prazo $(5$ anos); c) o budgeting, que é a definição da parcela anual dos diversos programas a incluir no orçamento estadual, para lhes dar autorização política e vinculação jurídica". ${ }^{72}$

70 BRASIL. Ministério do Planejamento, Orçamento e Gestão. Conhecendo mais sobre o Avança Brasil, p. 1.

71 PREMCHAND, A. Government budgeting and expenditure, p. 326.

72 FRANCO, Antonio L. de Sousa. Finanças públicas e direito financeiro, v. I, p. 423. 
No mesmo sentido das técnicas anteriormente mencionadas, o PPBS segue na linha da orçamentação voltada a integrar os orçamentos públicos ao sistema de planejamento, preocupando-se com os objetivos das ações governamentais.

\subsubsection{Orçamento base zero}

Outra técnica orçamentária que integra a evolução histórica dos orçamentos é o chamado orçamento base zero (zero-based budgeting - ZBB). Sua origem é atribuída à empresa Texas Instruments, que o aplicou em 1969, e foi implantada no setor público no Estado da Geórgia, pelo então Governador Jimmy Carter, em 1973, e no governo federal norte-americano em $1977 .{ }^{73}$

Surgiu principalmente em função da necessidade presente à época de contenção de gastos, tanto no setor público quanto privado, traduzindo, como registrou Nazaré Cabral, como "a primeira experiência de planeamento e orçamentação assumidamente orientada pela preocupação em conter o aumento da despesa, quer ao nível do setor privado (v.g. industrial), quer ao nível das administrações públicas". ${ }^{74}$

Consiste na técnica de "zerar" a cada orçamento a previsão das despesas, exigindo que os administradores públicos reavaliem cada programa, justificando as necessidades de despesas. Contrapõe-se ao método incrementalista, que ainda continua sendo aplicado (muito em função do insucesso da técnica do orçamento base zero), em que os orçamentos são elaborados com base nos orçamentos executados nos anos anteriores, com as modificaçóes ocorrendo de forma marginal, acrescentando-se (ou "incrementando-se") recursos às dotações já estabelecidas.

Tem como ideia central a permanente reavaliação das despesas e dos programas de cada órgão. ${ }^{75}$ Exige a cada nova elaboração orçamentária a reavaliação dos programas, questionando-se se as atuais ações governamentais são eficientes e eficazes, bem como se devem ser eliminadas ou reduzidas, para dar maior prioridade a outras ações ou mesmo para reduzir os gastos. ${ }^{76}$

73 PHYRR, Peter, The zero-base approach..., p. 253. Premchand registra a introdução de um modelo de orçamento base zero no Departamento de Agricultura norte-americano em 1962 (Government budgeting and expenditure, p. 334).

74 CABRAL, Nazaré da Costa. Programação e decisão orçamental. Da racionalidade das decisões orçamentais à racionalidade económica, p. 412.

75 CABRAL, Nazaré da Costa. Programação e decisão orçamental. Da racionalidade das decisões orçamentais à racionalidade económica, p. 412.

76 PHYRR, The zero-base approach..., p. 254. 
Tem importante papel no âmbito da melhoria na qualidade do gasto público, em face principalmente do incentivo que promove para "a revisão contínua dos programas e a eliminação dos gastos desnecessário e anacrônicos, bem como a permanência dos programas no orçamento seguinte, além de facilitar a realocação das despesas ano a ano", evitando "uma série de distorções causadas pela elaboração orçamentária de forma incrementativa, entre as quais se destaca a permanência de gastos desnecessários", como já ressaltado em texto de minha autoria. ${ }^{77}$ E colabora para mitigar efeitos indesejados da anualidade orçamentária, como ocorre com os gastos apressados em final de exercício voltados a "esgotar" as dotaçōes, ${ }^{78}$ mostrando-se mais contemporânea com a necessária adaptação a um sistema de planejamento que seja compatível com a plurianualidade.

As dificuldades em sua implementação e adoção por parte dos órgãos públicos, até mesmo por ser um mecanismo complexo, trabalhoso e custoso, ${ }^{79}$ colaboraram para que essa técnica não se disseminasse, resultando em uma experiência que não se consolidou, embora o tema volte com alguma frequência ao debate. ${ }^{80}$

\subsubsection{Orçamento por objetivos}

$\mathrm{Na}$ técnica denominada orçamentação por objetivos, destaca-se o modelo "target-base budgeting" (TBB), que consiste em um processo "de 'raciocínio top-down' que estabelece prioridades e define os limites de despesa no 'topo', forçando assim a escolha entre alternativas na 'base'” ${ }^{81}$ Os responsáveis maiores pelas decisões em matéria orçamentária (no caso do Brasil, na esfera federal, o Ministério do Desenvolvimento, Orçamento e Gestão), de posse das informações sobre a arrecadação, estabelecem objetivos e metas para os órgãos setoriais e, "com base

CONTI, José Mauricio. "Crise econômica pode criar o "orçamento recurso-zero". Levando o Direto Financeiro a sério, p. 241-244.

78 Como já discutido a respeito no texto de minha autoria "Natal é tempo de correr com a execução orçamentária”. Levando o Direto Financeiro a sério, p. 211-214.

79 Marc Robinson observa que a pretensão de rever cada programa todo ano mostrou-se por demais ambiciosa: "The failure of detailed comprehensive planning was particularly striking in the case of $\mathrm{ZBB}$. The attempt to review every program from bottom up every fiscal year - that is, to systematically consider all options ranging from cutting out programs to expanding them - proved to be impossibly ambitious" (Performance budgeting. Linking funding and results, p. 117).

80 Como mencionado no recém-citado texto "Crise econômica pode criar 'orçamento recurso-zero"', de minha autoria.

81 CABRAL, Nazaré da Costa. Programação e decisão orçamental. Da racionalidade das decisões orçamentais à racionalidade económica, p. 553. 
nas orientações políticas traçadas criam uma 'reserva' discricionária ou de acção política usada para um número diminuto de programas ou projectos”. É uma forma pela qual, de um lado, se estabelece "um sistema de decisão 'top-down', controlado a partir do centro, já que cabe aos decisores políticos centrais estabelecer as alocações pelos diversos serviços", mas, por outro, é também "um processo de descentralização da decisão política ao encorajar estes mesmos serviços a priorizar programas e projectos e a serem inovadores a partir da soma fixa que lhes é atribuída para a prossecução dos respectivos objectivos". ${ }^{82}$ A orçamentação por objetivos vem associada a um orçamento de programas, os quais devem ficar sob a responsabilidade de um gestor, que consome recursos para alcançar determinado objetivo político. ${ }^{83}$

Observa-se que, nessa técnica, a ênfase é dada para a forma de decisão a respeito da alocação de recursos, destacando-se a sistemática de estabelecer as prioridades pelos níveis mais altos e centrais da administração, descentralizando-se as decisões mais específicas sobre os programas para os órgãos mais próximos da execução.

A orçamentação por objetivos vem associada a um orçamento de programas, os quais devem ficar sob a responsabilidade de um gestor, que consome recursos para alcançar determinado objetivo político. ${ }^{84}$ Também há, nesse caso, uma forte conexão com os conceitos e as técnicas de gestão, em decorrência do movimento da "gestão por objetivos" (management by objectives - MBO), surgido no início dos anos 1970 a partir de experiências empresariais, que se transportaram para o setor público. O MBO, na síntese de Nazaré Cabral, consiste em "um processo no qual os objetivos organizacionais são traçados pelos membros respectivos em termos de resultados esperados", que se "assenta numa perspectiva de descentralização e de devolução de tarefas pelas diversas unidades da organização”, com os objetivos estratégicos definidos em nível central, e a implementação de responsabilidade dos gestores das diferentes unidades operacionais. ${ }^{85}$

O orçamento por objetivos, em sua versão atual, surgiu a partir do Relatório Gore, de 1993, preparado pelo então vice-presidente dos Estados Unidos, Al Gore

82 CABRAL, Nazaré da Costa. Programação e decisão orçamental. Da racionalidade das decisōes orçamentais à racionalidade económica, p. 554.

83 CABRAL, Nazaré da Costa. Programação e decisão orçamental. Da racionalidade das decisões orçamentais à racionalidade económica, p. 609-610.

84 CABRAL, Nazaré da Costa. Programação e decisão orçamental. Da racionalidade das decisões orçamentais à racionalidade económica, p. 609-610.

85 CABRAL, Nazaré da Costa. Programação e decisão orçamental. Da racionalidade das decisões orçamentais à racionalidade económica, p. 552. 
(gestão Bill Clinton), em que se constata a excessiva preocupação com os dados (inputs), no lugar dos resultados (outcomes), e indica a necessidade de fazer um planejamento de caráter mais estratégico, vinculando as despesas às prioridades e ao desempenho. Sugere, ainda, dar maior poder, liberdade e responsabilidade aos gestores, a quem caberia escolher as melhores opções a adotar, com menor rigidez na classificação e no uso das dotaçôes, podendo ficar com uma parte do que puderem poupar, eliminando o conhecido incentivo a esgotar as dotações, independentemente da utilidade e da necessidade dos gastos. ${ }^{86}$ Com isso, pretende-se construir um novo modelo de orçamento por objetivos, aperfeiçoando-se o performance budgeting, ao incorporar medidas de desempenho e avaliação de resultados, incluir novas formas de controle e responsabilização, associadas a sistemas de incentivos e sanções, o que exige uma reforma da administração pública, inserida em um quadro de reforma orçamentária que esteja integrada a um planejamento estratégico. ${ }^{87}$

Há ordenamentos jurídicos que acolhem expressamente o orçamento e a gestão por objetivos, como é o caso de Portugal, quando da Lei de Enquadramento Orçamental de $2001,{ }^{88}$ art. $60^{\circ}$, ao dispor que os

"orçamentos e contas dos organismos a que se refere o n. 1 do artigo $2^{\circ}$ devem ser objecto de uma sistematização complementar por objectivos, considerando a definição das actividades a desenvolver por cada organismo e respectivos centros de custos e tendo em conta a totalidade dos recursos envolvidos, incluindo os de capital, visando fundamentar as decisões sobre a reorientação e controlo da despesa pública: a) No conhecimento da missão, objectivos e estratégia do organismo; b) Na correcta articulação de cada área de actividade em relação aos objectivos; c) Na responsabilização dos agentes empenhados na gestão das actividades pela concretização dos objectivos e bom uso dos recursos que lhes estão afectos; d) $\mathrm{Na}$ identificação de actividades redundantes na cadeia de valor do organismo a justificada reafectação dos recursos nela consumidos".

\subsubsection{Planejamento estratégico e orçamento}

Mais recentemente, está-se desenvolvendo e aplicando aos sistemas de planejamento orçamentário governamental a técnica de planejamento estratégico.

86 CABRAL, Nazaré da Costa. Programação e decisão orçamental. Da racionalidade das decisões orçamentais à racionalidade económica, p. 554-555.

87 CABRAL, Nazaré da Costa. Programação e decisão orçamental. Da racionalidade das decisões orçamentais à racionalidade económica, p. 556.

88 Lei n. 91, de 20 de agosto de 2001. Diário da República, p. 5.352 e seguintes. 
O planejamento estratégico surgiu como um novo modelo que direciona as preocupações do governo para suas prioridades, fazendo da definição e da fixação de prioridades os focos principais, a partir das quais posteriormente serão verificadas as necessidades orçamentárias.

Há referências a outras denominações, embora menos utilizadas, como menciona Mauro Giacobbo, por exemplo, "planejamento corporativo abrangente”, "planejamento integrado abrangente" ou "planejamento estratégico situacional", mas, como ressalta,

"independentemente de denominação ou definição, o fato é que esse tipo de planejamento procura respostas a novas situações, por meio da interação com o meio ambiente e o estabelecimento de um sentido de direção. Ou seja, procura responder as seguintes perguntas: Para onde queremos ir? Qual a direção a ser seguida? Que caminhos escolher?”. ${ }^{89}$

É verdadeiramente a "carta de navegação" da nação na precisa e feliz definição de Fernando Albavera:

"La planificación estratégica es el instrumento de gobierno, que disponen las sociedades civilizadas, para definir la 'carta de navegación' de la nación. Esta precisa, jerarquiza y establece prioridades respecto de las razones de interés público, que los ciudadanos han invocado, para entregar atribuciones a los poderes públicos; y por tanto, define, la estrategia, las políticas, las metas y los objetivos". ${ }^{0}$

O planejamento estratégico abrange tanto o aspecto horizontal (intergovernamental/interministerial/interórgãos) quanto vertical (com o governo/um ministério/uma questão de política setorial), propiciando que os níveis políticos e administrativos identifiquem os objetivos prioritários, de modo que a decisão governamental acerca da alocação de recursos seja coesa, ${ }^{91}$ representando esta uma das mais difíceis tarefas do planejamento governamental, que é a de coordenar os diversos setores e níveis da administração pública para elaborá-lo e executá-lo.

No planejamento estratégico, importa mais o estabelecimento das prioridades e da missão dos órgãos governamentais, do que a especificação dos programas, ações, dotações e os exatos prazos a cumprir. Foca-se na estratégia, e não no

89 GIACOBBO, Mauro. O desafio da implementação do planejamento estratégico nas organizaçôes públicas, p. 7.

90 ALBAVERA, Fernando Sánchez. Planificación estratégica y gestión pública por objetivos, p. 8. E que se assemelha à figura que nos trouxe Fábio Comparato, mencionado no início deste trabalho (vide Capítulo 1).

91 OCDE. Achieving results through integrated strategic planning and budgeting. Slovenia: towards a strategic and efficient state, p. 69. 
orçamento propriamente dito. Espera-se que, havendo clareza nessas definições, a definição dos aspectos orçamentários venha como decorrência natural, alocando-se os recursos em programas alinhados com os objetivos estratégicos.

Cumpre ressaltar também o papel do planejamento estratégico como instrumento voltado a fazer previsões sobre o futuro, de modo a antecipar as situações e os cenários possíveis, permitindo os ajustes e direcionamentos na condução do órgão, preparando-o para as contingências e habilitando-o a respondê-las da forma mais adequada. ${ }^{92}$

A construção e a implantação de um modelo de planejamento estratégico, assim como ocorre em outros modelos, estão intrinsecamente ligadas à gestão; no caso, à ideia de gestão estratégica. A gestão estratégica pode ser compreendida como um "processo integrado de ações que permite: a identificação de objetivos político-estratégicos; a antevisão dos prováveis cenários futuros; a elaboração das mais adequadas soluções estratégicas para sua conquista; o permanente monitoramento do ambiente, que envolve a conquista desses objetivos; e a coordenação, no nível estratégico, de todo esse processo." ${ }^{33}$

O relacionamento com os ambientes interno e externo é também uma característica diferenciadora dessa metodologia, além de seu aspecto dinâmico, como ressaltado por Mauro Giacobbo:

"Nesse contexto, o processo de planejamento estratégico precisa ser essencialmente dinâmico, não se esgotando num plano. Requer uma equipe capaz de captar as coisas que estão acontecendo nos ambientes interno e externo, interpretá-las e aplicá-las com rapidez e, assim, dar continuidade ao processo. O plano é como um mapa de estrada: dá ao motorista uma ideia geral da localização e da direção a ser seguida, mas esse precisa estar permanentemente alerta para corrigir o rumo e atento para enfrentar o imprevisto". ${ }^{4}$

Há uma dificuldade, que se observa formar uma tendência, de os governos não estabelecerem claramente suas prioridades e objetivos político-estratégicos, o que prejudica, e até mesmo inviabiliza, a condução da administração de forma

92 Nesse sentido: MOTTLEY, Charles. Strategic planning. In: LYDEN, Fremont; MILLER, Ernest G. Public budgeting: program planning and evaluation, p. 127: "The specialized branch of the planning activity which is concerned with anticipating events, making diagnoses and shapping appropriate courses of action, so that an organization can be in the best position, ready and capable, to respond effectively to contingencies, is called strategic planning".

93 BRASIL. Núcleo de Assuntos Estratégicos da Presidência da República. Cadernos NAE, p. 272.

94 GIACOBBO, Mauro. O desafio da implementação do planejamento estratégico nas organizações públicas, p. 78. 
coerente e planejada, dada a falta de rumos a serem seguidos. Não é difícil notar, ainda hoje, na maior parte dos orçamentos e peças de planejamento orçamentário - com destaque para o PPA, no caso brasileiro -, que as prioridades são vagas, muitas vezes difíceis de serem identificadas precisamente..$^{5}$ Muitas razões podem justificar esse fato. Fixar prioridades representa fazer escolhas, o que evidentemente implica dar maior ênfase e importância a determinados setores, programas, regiōes, em detrimento de outros, que não serão priorizados. Escolhas no mais das vezes "trágicas", para usar a bem lançada expressão que intitula a obra de Guido Calabrese e Philip Bobbit, ${ }^{96}$ em que políticas públicas essenciais terão de ser por vezes reduzidas ou mesmo excluídas, em face de outras que merecerão maior atenção, dada a restrição orçamentária que não permitirá atender a tudo e a todos. A explicitação clara de prioridades - e consequentemente de "não prioridades" - gerará insatisfação aos não contemplados, o que é um ônus político não desejado pelos que ocupam os mais altos níveis da administração, regra geral eleitos pela população, e com compromissos de atender a muitos dos setores, grupos, regiões que o elegeram e que não aceitarão ficar excluídos. Mostra-se politicamente interessante manter uma opacidade na definição das prioridades com antecedência, fazendo com que as decisões que importem em escolhas passem a ser tomadas na fase de execução, de forma menos transparente, evitando-se a insatisfação dos não contemplados. $^{97}$

95 Nesse sentido, bem se ajustam as palavras de Osvaldo Maldonado Sanches ao tratar do tema: "Em nosso entender, a cada nova versão o PPA mais tem se afastado do intento dos Constituintes. O fato de este não despertar nos parlamentares o mesmo interesse que as leis orçamentárias, mais palpável e efeitos mais imediatos, tem contribuído para esse resultado, na medida em que enseja maior latitude de manobra ao Poder Executivo. De um início promissor (o PPA 1993-1995), que indicava projetos prioritários, definia prioridades, objetivos e metas por setores, regionalizava os detalhamentos e exigia lei específica para sua alteração, chegamos ao PPA 2000-2003, de grande generalismo (6 óbvias diretrizes estratégicas, que servem para qualquer nação do mundo; 28 macro-objetivos, maior parte dos quais de grande inespecificidade; 5 agendas, que cobrem o que escapou; quase 400 programas e milhares de ações). Em poucas palavras, um grande guarda-chuva que abrange qualquer iniciativa que se queira intentar durante o mandato governamental" (Plano plurianual e orçamento: inadequações entre normas práticas, problemas e desafios a vencer, p. 2).

96 CALABRESE, Guido; BOBBIT, Philip. Tragic choices: the conflict society confronts in the allocation of tragically scarce resources. Nova York: W. W. Norton \& Company, 1978.

97 Nessa linha, já me manifestei por mais de uma vez, como se pode ver em "Planejamento municipal precisa ser levado a sério", e "Planos de governo são essenciais para a escolha do próximo presidente", ambas publicadas em Levando o direito financeiro a sério (p. 135-138 e 129133, respectivamente). 
Explicitando, o PPA, um planejamento do ente federado para período de médio prazo, que só não coincide com o mandato do Chefe do Poder Executivo pelo fato de que este somente poderá elaborá-lo após assumir o mandato, tendo o prazo até o final do exercício financeiro para aprová-lo, ${ }^{98}$ é documento que deve refletir a estratégia do governo pelo período. Nesse sentido, espera-se que governos com prioridades diferentes explicitem-nas em seu PPA, produzindo documentos tão substancialmente diferentes quão diversas sejam as prioridades dos respectivos governantes. Mas não é o que se tem observado, ocorrendo, não poucas vezes, rupturas significativas no comando do governo, em que pessoas e partidos que se apresentam com propostas aparentemente bastante díspares, ao assumirem o mandato, produzam PPA com grande similitude entre si, não sendo muitas vezes possível notar com clareza eventuais diferenças nos rumos que se pretende - e, no caso, se espera - dar à administração.

Nesse sentido, o planejamento estratégico vem dar uma importante contribuição e representa um avanço, ao dar ênfase à necessidade de estabelecer as prioridades, primeiro e mais importante passo para implantar um planejamento adequado, coerente e eficiente. Não se pode esquecer que a essência do planejamento está justamente em definir e formalizar as escolhas, o que é fundamental para dar rumo à administração, e somente a partir daí organizar as políticas públicas, os programas e as ações com as respectivas dotações que constarão do orçamento.

O planejamento estratégico, segundo Nazaré Cabral, parte do princípio de que o planejamento conduz à eficácia, e que as organizações, seguindo um processo formal e metodológico, definiriam uma estratégia que se materializaria em um plano formalizado; no entanto, isso não se concretizou como esperado, dadas as incertezas da realidade atual e dificuldades de previsão. Com isso, o planejamento, mais formal, rígido e pouco criativo, deve ser substituído pela estratégia, que é informal, flexível e criativa. Surge assim a ideia de um planejamento estratégico mais flexível, que possa se adaptar às alterações da realidade circundante. ${ }^{99}$

Explicita com propriedade Allen Schick que o planejamento estratégico surge como uma inovação contrastante com outras reformas (como o orçamento-programa e o PPBS), por não ser condicionado ao tempo e às limitações financeiras do orçamento, mas, em contrapartida, não influencia diretamente o orçamento. A sua

98 Segundo as normas atualmente vigentes - ADCT, art. 35, $\$ 2^{\circ}$.

99 CABRAL, Nazaré da Costa. Programação e decisão orçamental. Da racionalidade das decisões orçamentais à racionalidade económica, p. 400. 
separação do orçamento permite que ele tenha um olhar mais abrangente dos objetivos e perspectivas, mas diminui, potencialmente, as chances de que o plano determine o orçamento. ${ }^{100}$

Embora essa priorização em definir os objetivos estratégicos, sem necessariamente uma ligação mais estreita com o orçamento, possibilite uma maior flexibilização por ocasião da elaboração das peças orçamentárias, adaptando-se com maior facilidade os orçamentos à realidade e às circunstâncias do momento, há que se reconhecer também um prejuízo à segurança jurídica nesse modelo.

Se o planejamento governamental, pelo que se pode constatar, tem dificuldades em se estabelecer como um sistema de normas claras, seguras e transparentes, que possa gerar elevado grau de confiança nos atores envolvidos, governamentais ou mesmo não governamentais, modelos como o de planejamento estratégico, que mitigam a clareza da relação entre o plano e o orçamento, não tendem a colaborar para aumentar a segurança jurídica do sistema. Pelo contrário, acabam tornando-o juridicamente frágil, menos efetivo e cada vez menos útil como instrumento de balizamento da ação do Estado a médio prazo, o que influencia também a ação dos demais atores, como os investidores privados, que terão diminuída sua confiança nas leis de planejamento como indicadores confiáveis dos rumos da ação governamental a médio prazo (e, evidentemente, mais ainda a longo prazo). E também, e principalmente, os vários entes federados envolvidos, uma vez que, nos estados organizados sob a forma federativa, muitas das políticas públicas são de abrangência nacional e dependem da cooperação entre eles para que se concretizem de forma eficiente, o que não se viabilizará sem normas jurídicas que ofereçam segurança e coesão ao sistema.

Sendo assim, é fundamental que o sistema de planejamento orçamentário governamental, ainda que seja adotado um modelo de planejamento estratégico, de modo a estabelecer, nos níveis mais elevados da administração, as estratégias governamentais, consubstanciadas nos objetivos estratégicos do ente federado, deve necessariamente fazê-lo acompanhado de um desdobramento deles construído de forma clara, relacionando-se com programas orçamentários que constarão das respectivas leis orçamentárias, com todos os elementos e especificações exigidos e que permitam concretizar os referidos objetivos, de modo transparente, e que possibilitem o controle social e dos órgãos competentes.

No modelo de planejamento orçamentário de médio prazo adotado pela administração pública federal pelo PPA federal 2012-2015, o planejamento estratégico

100 SCHICK, Allen. Does budgeting have a future? p. 25. 
cumpre essa função estabelecendo um sistema de planejamento em três níveis, ou "dimensões": a estratégica, a tática e a operacional, de modo a tornar os instrumentos de planejamento e orçamento complementares e integrados. Substituiu-se o binômio "Programa-Ação", que estruturava tanto o PPA quanto o orçamento, por Programas Temáticos, Objetivos e Iniciativas, ficando a categoria de Ação exclusiva para a lei orçamentária; o PPA passa a ter como foco "a organização da ação do governo nos níveis estratégico e tático, e o Orçamento responde pela organização no nível operacional". ${ }^{101}$ Sendo assim, as prioridades do governo são fixadas no âmbito da dimensão estratégica, pelos macrodesafios, e na visão de longo prazo. A dimensão tática define caminhos exequíveis para o alcance dos objetivos e das transformaçōes definidas na dimensão estratégica, vinculando programas temáticos aos objetivos, que se materializam nas iniciativas expressas no PPA. A dimensão operacional aparece no orçamento, no qual se materializarão a preocupação com o desempenho, a eficiência da ação governamental e a busca pela otimização na aplicação dos recursos disponíveis e na qualidade dos produtos entregues. ${ }^{102}$ Há, dessa forma, por meio das técnicas adotadas, um planejamento de caráter estratégico, que se materializa no PPA, em que se definem as prioridades estratégicas do governo, ao mesmo tempo que se fixam as ações com as quais serão atingidos, materializadas no orçamento, tornando-o operacional, com uma coordenação juridicamente formalizada nas leis de planejamento orçamentário. Um planejamento que deveria ser compatível com os princípios da boa gestão pública, levando em consideração objetivos, resultados e desempenho, com transparência e que podem ser mensurados e avaliados.

Contudo, não parece ter sido adequadamente elaborado e implantado, consoante se pode constatar das pertinentes críticas de Luiz Fernando Arantes Paulo, em obra na qual analisa o tema com profundidade. $\mathrm{O}$ autor chama a atenção para a alteração conceitual de programa, que "até o PPA 2008-2011 era caracterizado como instrumento de organização da ação governamental para a resolução de um problema ou o atendimento de uma demanda, (mas passou) a expressar simplesmente as entregas de bens e serviços relacionados a uma determinada política pública", aparentemente destoando do conceito de programa estabelecido na Constituição. $^{103}$ Embora considere um avanço em relação ao modelo anterior, a desvinculação da estrutura orçamentária promovida pelo PPA 2012-2015 permitiu

101 BRASIL. Ministério do Planejamento. Orientação para a elaboração do PPA 2012-2015, p. 9.

102 BRASIL. Ministério do Planejamento. Orientação para a elaboração do PPA 2012-2015, p. 10.

103 PAULO, Luiz Fernando Arantes. Plano plurianual. Teoria, prática e desafios para a sua efetividade, p. 97. 
a superação do entrave metodológico de que uma ação só gera um produto. Mas entende que deveria "ter preservado a figura do programa como unidade de gestão, como forma de fortalecer a integração entre plano, orçamento e gestão". E acrescenta que "O PPA 2012-2015 também fez uma opção clara pelo viés político do planejamento (...) superando a dualidade com o viés controle, que prevê a discriminação dos elementos de gasto e custo". Conclui assim que, "não obstante os avanços mencionados, sob a ótica de um instrumento de planejamento e gestão para resultados, o PPA 2012-2015 pode ser considerado um considerável retrocesso". ${ }^{104}$

O PPA federal 2016-2019 manteve na essência a estrutura do PPA anterior, o qual procurou aperfeiçoar, fazendo ajustes em aspectos em que puderam ser identificadas falhas na gestão do plano. Entre elas, "a aproximação entre a Orientação Estratégica e os Programas Temáticos, facilitando a compreensão de como a estratégica geral do governo se conecta com os objetivos e metas expostos na sua dimensão programática”. E ressalta a orientação no sentido de torná-lo um "instrumento mais estratégico, no qual seja possível ver com clareza as principais diretrizes de governo e a relação destas com os Objetivos a serem alcançados nos Programas Temáticos", para o que conta com Programas Temáticos que reflitam mais claramente as prioridades dos planos setoriais. ${ }^{105}$ As alteraçôes, como destacado na mensagem presidencial, concentraram-se basicamente em dois pontos, o reforço do "caráter estratégico do Plano, estruturando-o em uma Dimensão Estratégica, contendo uma Visão de Futuro e um conjunto de Eixos e Diretrizes Estratégicas", e a melhor qualificação do "conteúdo dos Programas Temáticos, que passam a expressar com maior clareza as escolhas estratégicas para cada área por meio de seus Objetivos e respectivas Metas, que por sua vez destacam de forma concisa as entregas mais relevantes e estruturantes para a implementação das políticas públicas". ${ }^{106}$

O planejamento estratégico guarda estreita relação com a gestão, e o sucesso de sua implementação e adequado funcionamento depende dessa inter-relação. Os estudos do Núcleo de Assuntos Estratégicos da Presidência da República ${ }^{107}$ sobre a

104 PAULO, Luiz Fernando Arantes. Plano plurianual. Teoria, prática e desafios para a sua efetividade, p. 113.

105 BRASIL. Ministério do Planejamento, Orçamento e Gestão. Secretaria de Planejamento e Investimentos Estratégicos. Orientaçôes para a elaboração do Plano Plurianual 2016-2019, p. 4.

106 BRASIL. Ministério do Planejamento, Orçamento e Gestão. Secretaria de Planejamento e Investimentos Estratégicos. Plano Plurianual 2016-2019, Mensagem presidencial, p. 10.

107 Responsável pela elaboração de importantes estudos sobre o planejamento de longo prazo, com construção de cenários futuros, como os que compõem o "Projeto Brasil 3 Tempos". 
gestão estratégica governamental deixam clara essa necessidade de coordenação entre as técnicas de gestão e o planejamento. O processo de gestão estratégica compreende um conjunto integrado de ações que permite "a identificação de objetivos político-estratégicos; a antevisão dos prováveis cenários futuros; a elaboração das mais adequadas soluções estratégicas para sua conquista; o permanente monitoramento do ambiente, que envolve a conquista desses objetivos; e a coordenação, no nível estratégico, de todo esse processo". ${ }^{108}$ Essa ação contínua mostra-se fundamental, pois a dinâmica da realidade exige um acompanhamento dos fatos e dos objetivos estabelecidos, a fim de mantê-los permanentemente adaptados às circunstâncias. Com isso, aperfeiçoa-se o sistema de planejamento estratégico, que, em sua versão "clássica" era estático, e a "instabilidade que envolvia o ambiente e o dinamismo da construção do futuro não eram considerados". Corrigiu-se essa deficiência, e

"o conceito de projeto foi direcionado para o de processo e o conceito de planejamento, para o de gestão. (...) Desses fundamentos surgiu a atual metodologia, que considera: (...) a permanente interação corretiva entre o plano teórico e a realidade, com a finalidade de realimentar o sistema, para adaptar a construção das curvas de futuro à realidade, sem perder o foco no objetivo". ${ }^{109}$

Nessa nova concepção, a "visão temporal, os cenários prospectivos e os objetivos estratégicos, por meio da metodologia de estudo de situação, permitirão a elaboração de diversas linhas de ação (que conterão) estratégias que respondam às clássicas perguntas relacionadas à aplicação do poder: quem? O quê? Quando? Como? Onde? Com que meios?", 110 e cada linha de ação "é estruturada por meio da identificação dos seus pontos de atuação, definidos pelo: 'quem', 'o quê', 'quando', 'onde', 'como' e 'com que meios". ${ }^{111}$ Podem ser estabelecidos objetivos de longo prazo, caso em que há que se identificar "períodos temporais intermediários, que facilitem a materialização progressiva da conquista do objetivo estratégico", devendo os pontos de ação estar amarrados "aos parâmetros de medição de desempenho, de modo a facilitar o acompanhamento da eficácia de sua ação sobre a curva de futuro considerada". ${ }^{112}$ A inter-relação entre gestão e planejamento evidencia-se na medida em que "um dos fatores que sustentam a necessidade de gestão estratégica

108 Núcleo de Assuntos Estratégicos. A metodologia de gestão estratégica do NAE. In: GIACOMONI, James; PAGNUSSAT, José Luiz (Org.). Planejamento e orçamento governamental, p. 271.

109 Núcleo de Assuntos Estratégicos. A metodologia de gestão estratégica do NAE, p. 272.

110 Núcleo de Assuntos Estratégicos. A metodologia de gestão estratégica do NAE, p. 277.

111 Núcleo de Assuntos Estratégicos. A metodologia de gestão estratégica do NAE, p. 280.

112 Núcleo de Assuntos Estratégicos. A metodologia de gestão estratégica do NAE, p. 282. 
ser considerada um processo e não um projeto é a sua necessidade de contínuo aperfeiçoamento, o que é muito facilitado se o conceito da aprendizagem contínua for assimilado em sua gestão". ${ }^{113}$

O planejamento estratégico passou a conceber o modelo de planejamento orçamentário governamental brasileiro a partir do PPA federal 2000-2003, no qual ocorreram significativas alterações na forma de elaboração e organização dos PPA no âmbito do governo federal, influenciando os demais entes federados. A nova concepção de planejamento, com foco em resultados, exigiu um planejamento mais flexível, como ressaltam Pares e Valle, "de vocação estratégica, que se atualiza em função do desempenho, por meio do monitoramento, da avaliação e da consequente revisão do Plano, diferentemente do planejamento clássico", com "um ciclo de aperfeiçoamento contínuo, típico da gestão privada (...) na figura do PDCA (PDCA = Plan (planejar), Do (fazer), Control (verificar) e Act (agir)" ${ }^{114}$ A legislação brasileira já o consagrou explicitamente na Lei n. 10.180, de 2001, que organizou os sistemas de planejamento e orçamento federal, estabelecendo que o "Sistema de Planejamento e Orçamento Federal tem por finalidade formular o planejamento estratégico nacional" (art. 20, I).

A Portaria MOG (então Ministério de Orçamento e Gestão) n. 42, de 14 de abril de 1999, reformulou as categorias orçamentárias, de forma a melhor articular o planejamento com o orçamento, estabelecendo o programa como elemento de integração entre o PPA e a lei orçamentária, estruturando-se de modo que o plano termine no programa e o orçamento comece no programa. Ronaldo Garcia destaca essas mudanças mostrando o avanço conceitual e metodológico, nessa articulação entre plano e orçamento, com a conceituação de função (que define as políticas governamentais), subfunção (que agrega um subconjunto de despesas), programa ("instrumento de organização da ação governamental, que visa à concretização dos objetivos pretendidos e é mensurado por indicadores estabelecidos no PPA”, como já mencionado) e suas modalidades de projetos, atividade e operações especiais. Há a eliminação das categorias de subprograma, subprojeto e subatividade, e a classificação orçamentária passa a ser exclusivamente funcional e subfuncional, preservando-se a lógica da organização matricial, que permite a combinação de subfunçôes com funções diferentes daquelas a que estejam vinculadas. Com a alteração da classificação programática por uma estrutura programática definida no PPA, e os

113 Núcleo de Assuntos Estratégicos. A metodologia de gestão estratégica do NAE, p. 283.

114 PARES, Ariel; VALLE, Beatrice. A retomada do planejamento governamental no Brasil e seus desafios, p. 239. 
programas devendo resultar em produtos, com metas e recursos definidos, viabiliza-se a gestão de um orçamento por resultados, imprimindo-se uma perspectiva gerencial, com atribuição de responsabilidades, possibilitando avaliações e cobrança de resultados. ${ }^{115}$

Um avanço que se mostrou mais teórico do que prático, pois, em sua implementação, registrou falhas. Destaca a utilização, para a construção dos programas, das informaçōes do PPA anterior (1996-1999), o que importa em "ingressar em um mundo novo olhando para trás e guiado por mapas referentes a um mundo velho", quando se poderia adotar algo mais próximo a um orçamento base zero, e assevera com propriedade: "Acredita-se ser melhor andar para a frente olhando para a frente - e não para trás. Afinal, o caminho se faz ao andar, ainda que com tropeços e riscos, mas abre maiores possibilidades para o exercício criativo de construção do novo". A lacuna na definição de "problema" também comprometeu, pois os planos e orçamentos passaram a ser estruturados por programas, cuja finalidade é justamente dar solução a um problema - tornando, obviamente, necessário identificar claramente o que é exatamente um problema, o que não é simples. Critica ainda que na elaboração dos programas deu-se indevido tratamento à previsão de recursos, efetuada com base na execução orçamentária dos exercícios anteriores, o que novamente evidencia o viés fiscalista e o "olhar para trás" (ou ainda, como bem expressa, "lanterna na popa"). ${ }^{116}$ Trata-se de um aspecto para o qual Mauro Giacobbo chamou a atenção, ao afirmar que o planejamento estratégico deve focar-se no futuro, e não no passado:

"O planejamento estratégico transforma a organização reativa em proativa. Isto é, a implementação do planejamento estratégico provoca uma mudança de enfoque na organização, que passa a direcionar a aplicação de esforços para eventuais erros futuros, em vez de se concentrar na análise do passado e no gerenciamento das situaçôes do presente". ${ }^{117}$

Como todos os métodos, pode-se ver nos itens anteriores, não é diferente com o planejamento estratégico o enfrentamento de dificuldades na implementação, que muitas vezes até mesmo comprometem e inviabilizam o seu uso.

115 GARCIA, Ronaldo Coutinho. A reorganização do processo de planejamento do governo federal: o PPA 2000-2003. In: CARDOSO JR., José Celso; CUNHA, Alexandre dos Santos (Org.). Planejamento e avaliação de políticas públicas, p. 35-36.

116 GARCIA, Ronaldo Coutinho. A reorganização do processo de planejamento do governo federal: o PPA 2000-2003, p. 36-40.

117 GIACOBBO, Mauro. O desafio da implementação do planejamento estratégico nas organizações públicas, p. 79. 
Ronaldo Garcia, já anteriormente citado, estudioso e especialista do tema, é incisivo ao afirmar que o planejamento estratégico não foi adotado como deveria, tendo sido

"menosprezado, permanecendo-se apenas com sua expressão material (físico-financeira), submetida a um enfoque normativo e economicista. Ignoraram-se as novas e muito mais complexas realidades política, social, cultural e econômica. Não foram considerados os avanços do conhecimento sobre os processos de governo nem as teorias e práticas de planejamento público moderno que buscam integrar as dimensóes e os recursos políticos, econômicos, cognitivos, organizativos e outros em perspectiva estratégica" ${ }^{118}$

\subsection{CONSIDERAÇÕES CRÍTICAS | AS NOVAS TENDÊNCIAS E OS OBSTÁCULOS E DIFICULDADES NA IMPLEMENTAÇÃO DAS TÉCNICAS ORÇAMENTÁRIAS}

Viu-se ao longo do exposto anteriormente uma multiplicidade e diversidade de técnicas e modelos de orçamentação e planejamento orçamentário da administração pública, que foram aplicados, estão sendo aplicados e pretendem ser aplicados no Brasil e em todos os demais países.

A análise não só do caso brasileiro, mas também de outros países, permite constatar que os sistemas de planejamento orçamentário e dos orçamentos públicos não usam necessariamente um único modelo ou técnica na construção do ordenamento jurídico que regula os respectivos sistemas. No mais das vezes, o que se vê nas complexas peças de planejamento e orçamento são conjuntos de demonstrativos em que se pode inferir haver a influência das várias técnicas citadas ao longo do que já foi exposto. Isso pode ocorrer em um mesmo país, até mesmo porque naqueles que se organizam na forma federativa os modelos de planejamento e orçamento não precisam guardar uma uniformidade absolutamente precisa em todos os entes da federação, mesmo porque isso seria inaplicável. Não há como se exigir um sistema único e uniforme de apresentação, apenas para citar o caso brasileiro, de um PPA de um município de 800 habitantes com o PPA federal.

O que se pode notar com clareza são algumas tendências na evolução das referidas técnicas orçamentárias, como é o caso do planejamento e da orçamentação voltados a resultados, ${ }^{119}$ ainda que possa haver diferenças e divergências quanto aos exatos detalhes encontrados nesse modelo.

118 GARCIA, Ronaldo Coutinho. A reorganização do processo de planejamento do governo federal: o PPA 2000-2003, p. 58.

119 "Since the middle of the 20th century, the pressure to spend more effectively and develop better budgeting techniques produced an almost universal acceptance that budgeting is not 
Isso está claramente refletido nos documentos de planejamento e orçamento brasileiros, como explicita o PPA 2012-2015 do Estado de São Paulo:

"O orçamento baseado em resultado consiste num conjunto de procedimentos integrados que objetiva melhorar a eficiência e a efetividade das despesas públicas através do uso sistemático de informaçôes de resultado para relacionar o financiamento das entidades do setor público conforme o desempenho por elas alcançado. Neste caso, a lógica do orçamento, geralmente orientada para o controle dos gastos, direciona-se para um enfoque de produção pública (desempenho). As características do orçamento por resultado podem gerar diversos benefícios para o governo e para a sociedade, incluindo a melhoria da priorização dos gastos, maior responsabilização pelos resultados, melhor projeção e gestão de programas e níveis mais elevados de transparência em relação ao destino e uso dos recursos". ${ }^{120}$

Situação na qual o governo estaria mobilizado para aperfeiçoar esses instrumentos no âmbito da Agenda Paulista de Gestão, ${ }^{121}$ constituída "para implantar um modelo de governança baseado em resultados, aprimorando a eficiência e a efetividade dos programas públicos" ${ }^{122}$ A gestão para resultado é um dos eixos do PPA 2012-2015 do Estado de São Paulo, comandada pela Secretaria de Planejamento e Desenvolvimento Regional (SPDR), que tem a responsabilidade de coordenar a elaboração de um plano desenvolvimento de longo prazo - o Plano São Paulo -, definindo um conjunto de ações, tanto no âmbito do setor público quanto privado, para fomentar o desenvolvimento. ${ }^{123}$

Outra tendência é a busca por uma administração mais eficiente, um anseio da população que se constata cada vez mais atual. Em análise sobre as manifestações populares ocorridas no Brasil em meados de 2013, o então vice-presidente da

only about planning for inputs, but also, perhaps primarily, about planning for the results that governments want to achieve", mostra Alta Fölscher, acrescentando que "the use of results-oriented budgeting by the United Nations as a precondition for AID assistance triggered its quick spread to the developing world" (Budget methods and practices, p. 119). E, ainda, a "contabilidade de compromissos pode ser vista já hoje como um elemento-chave das reformas (abrangentes) dos sistemas orçamentais”, como pontua Nazaré Cabral (Programação e decisão orçamental. Da racionalidade das decisões orçamentais à racionalidade económica, p. 563).

120 BRASIL. Governo do Estado de São Paulo. Secretaria de Planejamento e Desenvolvimento Regional. Plano Plurianual 2012-2015, p. 116-117.

121 Instituída pelo Decreto n. 56.643/2011.

122 BRASIL. Governo do Estado de São Paulo. Secretaria de Planejamento e Desenvolvimento Regional. Plano Plurianual 2012-2015, p. 12.

123 BRASIL. Governo do Estado de São Paulo. Secretaria de Planejamento e Desenvolvimento Regional. Plano Plurianual 2012-2015, p. 115-119. 
República, Michel Temer, considerou estarmos diante do que ele chama de "democracia eficiente". Segundo ele, a nova classe média que se mostrou presente nas manifestações passou a exigir não apenas aquilo que já havia conquistado, mas outra fórmula de democracia.

"A essa terceira eu chamo de democracia eficiente. Ou seja, passou-se a exigir maior qualidade nos serviços públicos prestados ao povo. Até porque quem não tinha carro e o adquiriu leva horas para chegar ao trabalho. Quando entra no metrô, em ônibus ou nos aviōes, encontra-os superlotados e incapazes de lhe oferecer um mínimo de conforto e dignidade. Passou-se a exigir eficiência. E essa busca fez com que muitos milhares de pessoas fossem às ruas". ${ }^{124}$

Abandonou-se inequivocamente o orçamento em sua versão tradicional, cuja preocupação voltava-se aos inputs, sem vinculação com o que se pretende obter a partir dos itens de despesa registrados.

Também a necessidade de um planejamento plurianual é inequívoca, não havendo mais como conceber sistemas orçamentários fundados em orçamentos exclusivamente anuais, desconectados de um sistema que compreenda peças orçamentárias de natureza plurianual. O fato é bem observado por Nazaré Cabral, ao ressaltar as "novas tendências que marcam os sistemas orçamentais (orientados por uma preocupação crescente de 'planejamento plurianual' das despesas, 'medium-term fiscal framework') e os sistemas contabilísticos contemporâneos (caracterizados pela adopção crescente da contabilidade de compromissos por oposição à 'tradicional' contabilidade de caixa)", ${ }^{125}$ que mostram ser fundamentais as previsões de médio e também longo prazos:

"Na verdade, num plano operacional, os Estados, conduzidos pela necessidade de olhar para o que vem a seguir no ano financeiro, têm apostado na construção de cenários financeiros agregados, geralmente para o médio prazo (de 3 a 5 anos), ainda que, por vezes, com projecçōes que respeitam períodos mais longos (10 a 30 anos, chegando a atingir os 75 anos)". ${ }^{126}$

No entanto, ainda que se constate ser este um caminho sem volta, as dificuldades encontradas para fazer valer esse modelo são bastante significativas, e o que se vê atualmente é um trabalho contínuo de aperfeiçoamento das técnicas, bem como das especificações de detalhes e formas de apresentação e confecção das

124 TEMER, Michel. Por uma democracia eficiente. Folha de S.Paulo, p. A5.

125 CABRAL, Nazaré da Costa. Programação e decisão orçamental. Da racionalidade das decisões orçamentais à racionalidade económica, p. 496.

126 CABRAL, Nazaré da Costa. Programação e decisão orçamental. Da racionalidade das decisões orçamentais à racionalidade económica, p. 497. 
peças de planejamento e orçamento, em uma ação conjunta com os conhecimentos de administração pública, na tentativa de vencer essas dificuldades para alcançar um modelo que se torne o mais próximo possível daquele que possa vir a ser considerado ideal.

A identificação de muitos desses obstáculos a se superar é relevante para que seja possível conhecer melhor a dimensão do problema, além de eventuais possíveis soluçôes, caminhos ou perspectivas de avanço.

Muitas dessas dificuldades ficam claramente evidenciadas e podem ser facilmente perceptíveis pelos que integram a administração pública e mesmo pelos que, fora dela, com ela se relacionam, sendo relatadas pelos estudiosos do tema.

Mauro Giacobbo, ao discorrer com muita propriedade sobre o desafio da implementação do planejamento estratégico no setor público, além de deixar claras as características e funções do planejamento estratégico, identifica muitos dos obstáculos enfrentados. O planejamento estratégico enfrenta resistência interna dos funcionários, em face das mudanças na filosofia de atuação da organização; os custos são altos, diante da necessidade de levantamento prévio de informações e realização de estudos; e é difícil de ser implementado, pois exige "dos dirigentes e demais participantes do processo alto nível de imaginação, capacidade analítica, criatividade, coragem para implementar mudanças e estabelecer estratégias e, acima de tudo, muita persistência, perseverança e disciplina". ${ }^{127}$

Vale reproduzir, dada a notável precisão, as observações que o autor destaca como comuns quando se cogita implementar inovaçóes no planejamento das organizações públicas brasileiras:

"Para que planejar? O brasileiro é diferente: ele tem jogo de cintura; ele sabe improvisar, na hora $\mathrm{H}$ ele sempre dá um jeitinho.

No Brasil, planejamento não pega. Aqui tudo é diferente, a começar do Governo que sempre muda tudo de uma hora para outra.

Se você não sabe para aonde vai (destino), todos os caminhos o levam para lá.

Não adianta tentar prever o que vai acontecer porque a realidade será sempre diferente.

As organizações precisam de pessoas que resolvam problemas, que tomem decisões imediatas, no presente, à luz dos fatos, com os pés no chão e não de futurólogos”. ${ }^{128}$

127 GIACOBBO, Mauro. O desafio da implementação do planejamento estratégico nas organizações públicas, p. 80.

128 GIACOBBO, Mauro. O desafio da implementação do planejamento estratégico nas organizações públicas, p. 82 . 
Essa verdadeira "cultura" de desprezo pelo planejamento, que está entre as principais dificuldades de concretizá-lo, exige um trabalho árduo no sentido de conscientização dos envolvidos que resulte na mudança dessa visão equivocada e que é a principal responsável pela inviabilização da introdução do planejamento no setor público.

Estevão Horvath observa que o povo brasileiro de forma geral não tem introjetada a cultura do planejamento:

"Infelizmente, não integra o rol de características do provo brasileiro, em geral, planejar. É fácil observar no dia a dia como as pessoas não atribuem grande importância - sempre generalizando aqui - ao planejamento. Essa cultura - ou a falta dela - se reflete no âmbito público, consoante se pode perceber no acompanhamento do andamento da atividade do Estado corriqueiramente". ${ }^{129}$

Entre os principais fatores que se pode detalhar como responsáveis por essa inviabilização da implementação do planejamento, Giaccobo enumera "a falta de adesão e de compromisso da administração superior com o planejamento, a descontinuidade administrativa, a verticalização excessiva, a falta de interação intraorganizacional, o descompasso entre planejamento e orçamento, com ênfase excessiva no cumprimento desse último, e a resistência a mudanças". E, ainda, os fatores burocráticos, como normas de responsabilidade hierárquica e divisão de trabalho que limitam a ação dos planejadores, levando à frustração e ineficiência. ${ }^{130}$

Silva e Gonçalves, tratando sobre o mesmo tema, ratificam boa parte dessas assertivas $^{131}$ e acrescentam ainda vários outros empecilhos que dificultam a introdução da cultura do planejamento, como a visão de servidores de que isso não se aplica a instituições que não visam ao lucro e a visão departamentalizada que os servidores têm de suas tarefas, prejudicando a visão holística da organização. ${ }^{132}$

É possível sistematizar essas dificuldades sobre as quais já se fez referência de modo a identificar com mais clareza os obstáculos que têm sido e continuarão a ser enfrentados.

${ }^{129}$ HORVATH, Estevão. O orçamento no século XXI: tendências e expectativas, p. 275.

130 GIACOBBO, Mauro. O desafio da implementação do planejamento estratégico nas organizaçóes públicas, p. 90-91.

131 Como a descontinuidade administrativa, gerada pela troca da administração, que, em vários órgãos públicos, ocorre de dois em dois anos, "acarretando falta de continuidade nos projetos em andamento" (é o caso do Poder Judiciário, tema que será abordado mais adiante em tópico específico). Revista de Administração da UFSM, p. 465.

132 SILVA, Flávia de Araújo; GONÇALVES, Carlos Alberto. O processo de formulação e implementação e implementação de planejamento estratégico em instituições do setor público. Revista de Administração da UFSM, p. 465. 


\subsubsection{Complexidade do planejamento e orçamentação no setor público}

De início, reiterando e ratificando o que já se expôs anteriormente, nunca é demais ressaltar que planejamento e orçamento no setor público é um tema complexo, uma vez que as dificuldades já significativas encontradas no setor privado nessa área são potencializadas em face das especificidades encontradas no âmbito governamental.

O orçamento no setor público é substancialmente diferente do orçamento no setor privado, ressalta Fölscher. Há uma dificuldade em se estabelecer parâmetros claros para definir os limites de despesas, gastos e respectivas fontes de financiamento. Identifica o autor com precisão que a dinâmica em que se contextualiza o orçamento público é bastante peculiar, pois no setor público não se gasta dinheiro com o objetivo de ganhar mais dinheiro, mas sim para atingir uma gama de finalidades de interesse público, muitas delas intangíveis. Mais do que isso, no orçamento público os objetivos, resultados e metas são complexos e de difícil mensuração, e podem estar relacionados apenas indiretamente com as atividades que estão sendo financiadas. Acrescenta-se a esse contexto um ambiente político muitas vezes conflituoso, em que não está presente o objetivo preciso da obtenção de lucro, não há incentivos claros para a redução de custos com a finalidade de aumentar o lucro, existem dificuldades para medir o desempenho e mecanismos falhos de sanção e recompensa, em decorrência das práticas já arraigadas no serviço público. ${ }^{133}$

$\mathrm{Na}$ mesma linha, segue Giacobbo, quando, ao discorrer sobre o planejamento estratégico, evidencia que

"o planejamento estratégico nasceu e se desenvolveu voltado basicamente para o setor privado, cujos objetivos, características e condições de atuação são bem diferentes do setor público. Muitas das premissas válidas para o mundo dos negócios não se aplicam a maior parte do setor público. (...) As ações das organizações públicas não são baseadas na competição, nem são administradas ou avaliadas por ganhos ou perdas de mercado. $\mathrm{O}$ desenvolvimento e a legitimação destas baseiam-se na concretização dos objetivos sociais que justificam a sua existência na ambiência em que operam". ${ }^{134}$

E nem tudo que é feito pelo setor público pode ser medido, em razão da diversidade de atividades que o governo deve desempenhar. Curristine distingue três tipos de programas: tangíveis; intangíveis feitos para um caso específico; e intangíveis feitos para uma situação ideal. Mostra que os indicadores de desempenho são

133 FÖLSCHER, Alta. Budget methods and practices, p. 109.

134 GIACOBBO, Mauro. O desafio da implementação do planejamento estratégico nas organizaçôes públicas, p. 91. 
mais facilmente aplicáveis nos programas que envolvem um bem tangível ou serviço cuja quantidade produzida é facilmente mensurável, como emissão de passaportes ou carteiras de habilitação, sendo mais fácil criar medidas de avaliação de custos unitários para esses tipos de atividades. ${ }^{135}$

Essas dificuldades, bastante claras por todos que conhecem a administração pública, mostram-se presentes de forma evidente nos modelos de planejamento e orçamentação baseados em resultados.

Osborne e Gaebler, na clássica obra Reinventing government, ao abordar o tema no Capítulo 5 ("Results-oriented government: funding outcomes, not inputs"), mostram exemplos de distorçôes causadas pela dificuldade na implementação de técnicas baseadas em resultados. Citam o caso ocorrido no Departamento de Assistência Social do Estado de Illinois, no programa que contemplava enfermos que recebiam tratamento domiciliar. O pagamento era feito de acordo com o nível de tratamento ministrado: para os doentes mais graves, o pagamento era maior; para os doentes que necessitavam de menos cuidados, o pagamento era menor. $\mathrm{O}$ que parecia ser um método bastante coerente mostrou resultados desastrosos. $\mathrm{O}$ objetivo da política pública implantada era dar alta aos idosos enfermos o mais cedo possível, para minimizar custos, mas o percentual de tratamentos domiciliares tornou-se crescente. Aparentemente, ao pagar mais para pacientes mais graves, que precisavam ficar acamados, o poder público deu um incentivo aos enfermeiros domiciliares a mantê-los acamados, desincentivando-os a fazê-los levantar, envolvê-los em atividades físicas, e ajudá-los a se tornar independentes. Pelo fato de a fórmula de financiamento focar nos inputs, ignorando os outcomes, acabou produzindo o efeito exatamente contrário da intenção do governo. ${ }^{136}$

Em sentido semelhante, já foi identificado o problema no âmbito do Poder Judiciário, em texto de minha autoria, constatando que a este poder cabe a missão de "promover Justiça", ação cujo objetivo é claramente intangível, difícil - se não impossível - de ser precisamente descrito, e, consequentemente, mensurado, inviabilizando a formulação de resultados e metas adequados. Programas voltados ao setor utilizam-se de atividades indiretamente relacionadas com a missão e os objetivos esperados, como "ações julgadas", "taxa de processos julgados", e outras que não representam com fidelidade o que se espera alcançar com o serviço prestado pelo órgão. ${ }^{137}$

\footnotetext{
135 CURRISTINE, Teresa. Government performance. Lessons and challenges, p. 145.

136 OSBORNE, David; GAEBLER, Ted. Reinventing government: how the entrepreneurial spirit is transforming the public sector, p. 138.

137 CONTI, José Mauricio. A autonomia financeira do Poder Judiciário, p. 125-135.
} 


\subsubsection{Desprezo dos governantes pelo planejamento e falta de cultura do planejamento na burocracia estatal}

Outra distorção importante, já mencionada no início deste item, e destacada por Osborne e Glaeber, está no fato de que os políticos não têm preocupação com o desempenho da administração pública, mas sim com a imagem e a ideologia. Normalmente, observam os autores, os políticos são reeleitos com base na imagem que os eleitores e grupos de interesse fazem deles, e não em quão bem seu governo presta serviços. E são os políticos que ocupam os principais cargos públicos, não os gerentes. Reproduzem as palavras de Michael Blumenthal, ditas após ter integrado o gabinete do Presidente Carter: "You learn very quickly that you do not go down in history as a good or bad Secretary in terms of how well you ran the place"; em Washington, "you can be successful if you appear to be successful". ${ }^{138}$ Embora ditas há décadas, são palavras que soam como se tivessem sido pronunciadas hoje. Observam-se cada vez mais a importância e a preocupação dos políticos - e consequentemente dos principais gestores da administração pública - com o "marketing", tendo suas decisões e ações sendo no mais das vezes guiadas não pelas sugestôes dos técnicos específicos de cada área envolvida, com as opções dos caminhos mais adequados para atingir os melhores resultados, mas sim por aquelas que avaliam o impacto imediato da decisão na opinião pública, o que nem sempre é mais adequado do ponto de vista dos critérios de eficiência, eficácia e efetividade voltados a alcançar os objetivos buscados pelo ente federado. Vê-se claramente uma valorização da "aparência" em detrimento da "eficiência", tornando regra que a primeira se sobreponha à segunda como critério para a tomada de decisões.

Também não se vê empenho, não somente dos governantes, mas também dos próprios servidores públicos, pela cultura do planejamento. Poucos são os que efetivamente dão atenção, no âmbito do setor público, em que a cobrança por metas e resultados é mais difícil de ser implementada, aos objetivos de médio e longo prazos da administração pública. O alerta de José Celso Cardoso é certeiro:

"Qualquer iniciativa de planejamento, dada sua natureza tecnopolítica crucial aos desígnios do país, apenas se fará crível se estiver institucionalmente situada e/ou fortemente referendada e amparada pelos mais altos escalóes políticos e instâncias formais da República brasileira. Qualquer iniciativa de planejamento desenvolvida à margem dessa condição, porquanto exigida constitucionalmente, estará inevitavelmente fadada ao fracasso". 139

138 OSBORNE, David; GAEBLER, Ted. Reinventing government: how the entrepreneurial spirit is transforming the public sector, p. 140.

139 CARDOSO JR., José Celso. Princípios e propostas para o PPA 2016-2019. Boletim de Análise Politico-Institucional 6, p. 18. 
O desapreço pelo planejamento pode ser constatado não só pela observação dos que integram a administração pública e testemunham a pouca relevância que se dá à questão, mas também pela análise de estudiosos que se deparam com o tema, como foi o caso da professora e urbanista Raquel Rolnik. Ao criticar a posição do Governador de São Paulo por ocasião da crise hídrica, quando teria dito que os planos seriam um "papelório inútil" para ficar na gaveta, a professora afirma que isso simplesmente revela

“o que todos sabem e ninguém admite. Parece haver uma espécie de consenso em nosso país de que planejamento é algo totalmente inútil, que não serve para nada. Assim, elaboram-se planos já sabendo que não serão cumpridos. Os rituais de elaboração desses planos, em geral, percorrem um caminho paralelo, nada convergente com as decisões tomadas no âmbito da gestão pública”.

E segue, expressando com muita propriedade o que não é difícil de constatar: "As gestôes, então, odeiam planos, já que estes as 'engessam', tirando a liberdade de decisão de cada mandatário eleito. Nessa lógica, não há mesmo lugar para o planejamento. Ou melhor, há: na gaveta, como bem afirmou o governador”. Referindo-se sobre a experiência em sua área específica de atuação, o planejamento urbano - que, em termos de planejamento, no que tange às críticas formuladas, vê-se não diferir do que se observa no âmbito do planejamento orçamentário -, diz: "Abundam os planos, mas estes são discursos que encobrem os reais processos de tomada de decisão sobre o que será feito em nossas cidades. Isso se define diretamente e discricionariamente por acertos entre os poderes político e econômico, em canais de interlocução que não passam pela esfera do planejamento”. Em seguida, formula e já responde à dúvida que surge em todos que se debruçam sobre o tema: "Se os planos não funcionam como antecipação pactuada de transformações de longo prazo, porque baseadas em opções com diferentes implicações para o futuro, por que então fazemos planos?”. Para ela, a resposta passa pelas milhares de páginas - o "papelório" - produzidas pelos consultores e consultorias que se alimentam desse mercado produtor de material destinado a subsidiar decisóes que não serão tomadas, uma vez que o político gestor (no caso, o governador) "decide o que e como fazer, na hora que bem entender". O que é ruim, por impedir a participação democrática nas decisóes e que o planejamento seja um instrumento que, se elaborado com transparência e participação social, seja "um instrumento fundamental da democracia, que nosso modo de operar teima em desconstituir". E conclui: "É por isso que hoje, mais do que nunca, planejar de verdade, de forma aberta e participativa, é um dos principais desafios de qualquer gestão. Eu ousaria dizer que planejar, e implementar o planejado, no Brasil hoje, é revolucionário”. ${ }^{140}$

140 ROLNIK, Raquel. Planejamento inútil. Folha de S.Paulo, 2015. 
A frequência, a gravidade e a intensidade de problemas que exigem solução imediata tendem a ocupar a agenda dos burocratas, que passam a agir apenas voltados a resolver problemas imediatos, sem preocupação com a identificação das causas e em evitar que voltem a se repetir, com medidas preventivas e busca de soluçôes para casos futuros. Agem os burocratas, no mais das vezes, apenas "apagando incêndios", como verdadeiros "bombeiros" da administração pública, ${ }^{141} \mathrm{sem}$ a conscientização de que, não havendo medidas concretas de planejamento, os problemas voltarão a ocorrer e invariavelmente aumentarão de intensidade, já que as causas não foram debeladas, nem se pensaram em soluçóes para corrigi-las.

Trata-se de um prejuízo que afeta diretamente a hoje tão almejada qualidade do gasto público, que, como bem pontuado por Élida Pinto recentemente, decorre principalmente de um déficit de planejamento suficiente, não havendo

"coerência ao longo do tempo entre o conteúdo dos sucessivos instrumentos de planejamento estatal e a sua ação prática, tampouco o controle é capaz de retroalimentar o planejamento, já que muito precariamente aquele orienta esse sobre como aprimorar seus déficits de compreensão e cobertura. Assim superpostas as mazelas, vemos um perfil de gestor, que se revela como um contínuo gerador de respostas de curto fôlego, para problemas longevos, como que mitigando o incêndio daquele dia, de modo a não enfrentar suas causas, apenas remediando suas consequências opacamente. Desse modo e apenas para fins de paroxismo analítico, o cenário pode ser reduzido à grosseira simplificação, segundo a qual a gestão pública brasileira atende aos controles formais como se fora o bastante e oferta à sociedade um manejo de soluções fundadas na metodologia primária de tentativa e erro. Sem incorporação de aprendizagem e sem continuidade dos serviços públicos, vivemos - a cada mudança de mandatário eleitoral - esforços caudalosos de começar o que já estava em curso, porque não sabemos fazer correções intermediárias e aprimorar planos que alcancem mais de um mandato eletivo". ${ }^{142}$

O aspecto cultural que dificulta a implementação de um bom planejamento, notadamente no que tange à sua efetiva execução, é observado por muitos autores. Ronaldo Garcia destaca a necessidade de conscientização dos responsáveis pela implementação do planejamento estratégico:

141 Expressão que utilizei por várias vezes, como se pode ver em "Decisões financeiras fundamentais são tomadas na Lei de Diretrizes Orçamentárias", "Direito financeiro precisa avançar, e a hora é agora" e "LDO é instrumento eficiente para a administração pública", "Colapso financeiro leva ao caos social e à intervenção federal no Rio de Janeiro", entre outros textos na mesma obra (Levando o direito financeiro a sério).

142 PINTO, Élida G. Controle das políticas governamentais e qualidade dos gastos públicos: a centralidade do ciclo orçamentário. Revista do Tribunal de Contas do Estado de Minas Gerais, p. 10 . 
"Construir um sistema de planejamento estratégico público que seja um poderoso instrumento de governo requer, antes de mais nada, que se tenha consciência de sua necessidade. E não há indícios seguros de que essa consciência esteja generalizada entre dirigentes públicos, parlamentares, quadros técnicos superiores, universidades, partidos políticos. O tamanho dessa deficiência pode, inclusive, ser tomado como indicador de nosso atraso político-institucional. Mudar um sistema de planejamento é tarefa hercúlea. A mudança, para deitar raízes profundas, tem que se dar primeiro nas mentalidades. E mudar cabeças não é fácil". ${ }^{143}$

Soma-se a isso uma verdadeira cultura de aversão ao planejamento, substituída pela cultura de viver o dia presente, aguardando os problemas surgirem para, só então, pensar como resolvê-los, e de forma improvisada, e não sistematizada. Órgãos de planejamento têm sua importância superada pelos órgãos de "gerenciamento de crise". Agir reativa e improvisadamente em face dos acontecimentos parece ser o princípio que rege as relações sociais e, infelizmente, também públicas, causando transtornos e prejuízos à administração pública, cujas dimensão organizacional e necessidade de coordenação entre os diversos atores governamentais e não governamentais não prescindem de um sistema coeso e juridicamente seguro de planejamento, permitindo que a transparência dos atos atuais e futuros da administração pública possam direcionar as ações de toda a sociedade.

\subsubsection{Leniência dos sistemas de fiscalização e inoperância dos mecanismos sancionatórios com relação ao planejamento}

Os orçamentos públicos, como já dissemos, têm a relevante função de controlar as atividades financeiras governamentais.

As peças orçamentárias, anuais e plurianuais, devem ser dotadas de precisão e clareza em razão não apenas de conduzirem e orientarem corretamente a ação governamental, mas também de permitirem a fiscalização e o controle por parte do sistema formal previsto na Constituição para exercer essa missão, bem como dos mecanismos de controle social da atividade financeira do Estado.

O conteúdo das leis orçamentárias, no caso brasileiro, em que as peças orçamentárias estão formalizadas em leis, com todas as suas especificidades, incluindo os demonstrativos nos quais estão consignadas as dotações em programas com objetivos, resultados, metas, descrição de atividades ou projetos, compõem a norma jurídica a ser cumprida e fiscalizada.

143 GARCIA, Ronaldo Coutinho. A reorganização do processo de planejamento do governo federal: o PPA 2000-2003, p. 51. 
No entanto, não é a praxe que se tem observado no sistema formal de fiscalização financeira e orçamentária, e menos ainda nos mecanismos de controle social.

Os órgãos de controle não são rigorosos com relação à aferição do cumprimento de metas, persecução de objetivos e alcance de resultados. Não obstante sejam realizadas auditorias em órgãos e acompanhamento de programas e políticas públicas, havendo eventualmente observações e recomendações, estas não resultam em reconhecimento de descumprimento do Plano Plurianual, da Lei de Diretrizes Orçamentárias e da Lei Orçamentária Anual. Mesmo porque há de se registrar a existência de programas vagos e imprecisos, capazes de abarcar ações e respectivos elementos de tal forma abrangentes, usualmente conhecidos como "guarda-chuvas", que dificultam o exercício de uma fiscalização mais precisa e rigorosa.

Regra geral são recomendações de aperfeiçoamento de programas ou itens em que se compõem, como indicadores inadequados, ou sugestôes genéricas decorrentes das apurações dos dados coletados. No parecer sobre as contas do governo federal referente ao exercício de 2012, por exemplo, o Tribunal de Contas da União concluiu que,

"Apesar da prioridade estabelecida pelo governo federal, existem desafios relacionados ao planejamento, ao financiamento e a execução das ações e serviços públicos de saúde, tendo em vista a gestão compartilhada do SUS, além das diferenças econômicas, sociais e geográficas existentes entre as regiōes do país. Seu enfrentamento requer articulação federativa, com vistas à garantia do acesso da população a serviços de qualidade, com equidade e em tempo adequado ao atendimento das necessidades de saúde, de forma a proporcionar o crescimento econômico e o compartilhamento equitativo de seus benefícios, além da melhoria das condiçōes de saúde da população". ${ }^{144}$

E estabelece cinco recomendações, entre as quais a de publicar a Programação Anual de Saúde (PAS), revisar portarias que tornem compatíveis as datas de realização das conferências de saúde com a elaboração do PPA, revisar portarias relacionadas com a articulação de conselhos, alteração de indicadores do Programa Saúde na Escola e ajuste nos indicadores que permitam o monitoramento de metas do PPA relacionadas com os complexos reguladores de saúde. Ou ainda:

"O Ministério da Saúde informou que, no ano de 2012, foram implantadas 46 novas centrais de regulação. Os dados disponibilizados para monitoramento da meta são diferentes da métrica do PPA, de implantação de complexos reguladores, o que torna difícil avaliar o cumprimento dessa meta, haja vista as diferenças na natureza desses dois tipos de unidades, conforme as disposições da Política Nacional de Regulação do

144 BRASIL. Tribunal de Contas da União. Relatório e parecer prévio sobre as contas do Governo da República. Exercício 2012, p. 518. 
SUS (Portaria GM/MS 1.559/2008). Assim, propõe-se recomendar ao Ministério da Saúde que incorpore, no monitoramento das metas do PPA 2012-2015, informaçôes relativas à implantação de complexos reguladores, além das centrais de regulação, em virtude da divergência encontrada entre a forma de acompanhamento do processo regulatório do SUS e aquela proposta no programa temático Aperfeiçoamento do SUS”. ${ }^{145}$

Não há, como se vê, no sistema de fiscalização, como se constata da ação do controle externo ora exemplificada, um rigor no acompanhamento dos aspectos relacionados com o planejamento, especialmente no que tange ao cumprimento do que foi estabelecido para os períodos mais longos, com atuação mais repressiva, aplicando-se as sanções eventualmente cabíveis.

\subsection{AS TÉCNICAS ORÇAMENTÁRIAS E SUA APLICAÇÃO NO PLANEJAMENTO ORÇAMENTÁRIO GOVERNAMENTAL BRASILEIRO}

Depreende-se, em função das interpretações dadas pelos diversos autores às expressões analisadas que cuidam das diversas técnicas de orçamentação às quais se fez referência, haver uma diversidade delas, cada uma com características próprias e também comuns.

Não se pode reconhecer com clareza, como vários dos autores mencionaram, existir uma definição nítida de cada uma, que permita identificar gêneros e espécies perfeitamente delimitados. Mesmo porque as várias técnicas, em geral, apresentam enfoques diferentes na forma de orçamentação, e não necessariamente nos mesmos aspectos.

Pode-se constatar que os orçamentos públicos são peças extremamente complexas, cujas funções, formas de elaboração e apresentação evoluíram ao longo do tempo, e também em diversos órgãos governamentais, países e regiōes, de forma nem sempre linear, por vezes incorporando conceitos e técnicas do setor privado, o que impede estabelecer que essa evolução tenha seguido um caminho absolutamente uniforme.

Os diversos modelos, com suas similaridades e variações, representam no mais das vezes conjuntos de técnicas e conceitos que se inter-relacionam e evoluíram no tempo e no espaço para conduzir à elaboração da peça orçamentária, associadas também por vezes a técnicas e conceitos de gestão.

145 BRASIL. Tribunal de Contas da União. Relatório e parecer prévio sobre as contas do Governo da República. Exercício 2012, p. 526. 
A evolução que se observa tem pontos de convergência, como se pode aferir do abandono do conceito de orçamento clássico ou tradicional, como aquela peça restrita a retratar informaçóes financeiras, de previsão de receitas e despesas, sem preocupações com os objetivos a serem atingidos, para uma concepção de orçamento cuja preocupação seja voltada justamente aos fins, com a alocação dos recursos feita de forma a atingi-los, com efetividade, eficácia e eficiência, otimizando o uso do dinheiro público em função do bem comum.

No Brasil, a Lei n. 4.320, de 1964, ao estatuir normas para a elaboração e o controle dos orçamentos públicos, instituiu o orçamento por programas, ao determinar que a lei de orçamento contenha "a discriminação da receita e despesa de forma a evidenciar a política econômico-financeira e o programa de trabalho do Governo", com anexo de "quadro demonstrativo do programa anual de trabalho do Governo, em termos de realização de obras e prestação de serviços” (art. 20), que deverá ser coerente com o Plano Plurianual, pormenorizando a etapa que será dele realizada no exercício (Decreto-lei n. 200, de 1967, art. 16).

Vale registrar, na evolução histórica das técnicas orçamentárias utilizadas no sistema de planejamento orçamentário brasileiro, a sistematização contida no trabalho de Francisco, Faria e Costa, que identificam de forma bastante pertinente a modificação do papel experimentado pelo orçamento. Identificam uma primeira fase que é conhecida como prática orçamentária unidimensional, ou seja, com ênfase apenas na esfera da despesa pública e nas receitas necessárias para fazer frente a esses gastos. A partir de então, o orçamento-programa daria uma nova ideia de bidimensionalidade no planejamento governamental orçamentário, passando a pergunta do "como gastar" para o "em que gastar". Entretanto, somente com o a evolução desse conceito para o Planning-Programming-Budgeting System (PPBS), em uma lógica tridimensional, é que o orçamento passa a ser considerado uma etapa de curto prazo no planejamento. ${ }^{146}$

A sistematização do processo do PPBS em três fases elaborada por Nazaré Cabral permite identificar alguns aspectos relevantes na comparação com a organização do sistema brasileiro de planejamento orçamentário governamental.

O PPBS, embora compreenda um processo integrado, uniforme e coerente, permite, como esclarece a autora, uma identificação de três fases que podem ser analisadas em separado, conforme os momentos que o integram. A primeira fase é a de planejamento, na qual se definem os objetivos, que são "a expressão quantificada

146 FRANCISCO, Jailton G; FARIA, Maria Leonor V.; COSTA, Helder G. Planejamento e orçamento públicos: uma revisão da literatura, passim. 
das missões, consistindo estas por sua vez na expressão da finalidade última de uma qualquer organização", e com essa quantificação se torna viável identificar os meios necessários para a concretização dos objetivos, bem como permitir o controle. A segunda fase ela denomina Programação: "uma vez determinadas as missões e fixados os objectivos, é possível organizar os meios necessários para os alcançar", e "o produto desta organização de meios redunda na elaboração de um programa". É considerada uma etapa fundamental no processo de otimização das decisões, pois nela cada objetivo estratégico, estabelecido na fase de planejamento, "determina uma categoria de programas, ou simplesmente, de um programa”. E a terceira fase, chamada de Orçamentação, corresponde àquela em que, "depois de tomadas as decisões referentes aos elementos dos programas, os recursos existentes são objecto de cálculo e a sua aquisição é organizada; no caso das administrações públicas, a decisão de aquisição é feita através do processo orçamental ou da orçamentação" ${ }^{147}$

Nessa mesma linha, é interessante mencionar a lição de Cabral de Moncada, que, ao explicitar o modelo norte-americano, que prefere dar maior ênfase à liberdade dos agentes econômicos, substitui a chamada "planificação econômica" pela classificação das despesas na forma do performance budget, o que permitiria suprir as desvantagens da ausência de planificação sem violar os princípios do liberalismo econômico. Com isso, não haveria um plano nem um "orçamento econômico", mas sim um "planning" orçamentário. ${ }^{148}$ A detalhar a metodologia da classificação das despesas orçamentais, especifica sua composição em três fases: a) planificação, com a fixação de objetivo de longo prazo a seguir pela Administração; b) programação, na qual há a concretização das tarefas a médio e curto prazo, elegendo-se as linhas de ação a executar; e c) orçamentação, quando ocorre a inscrição no orçamento dos valores anuais atribuídos aos programas estipulados. ${ }^{149}$

No processo de planejamento governamental brasileiro, a primeira fase, de "planejamento", constata-se ocorrer de múltiplas formas. Inicialmente, é possível reconhecer a identificação do que podemos chamar "grandes objetivos", ou, usando a própria expressão do legislador constituinte, "objetivos fundamentais da República Federativa do Brasil”, como aqueles já definidos no art. $3^{\circ}$ da Constituição. A delimitação mais precisa e específica desses objetivos ocorre de forma difusa,

147 CABRAL, Nazaré da Costa. Programação e decisão orçamental. Da racionalidade das decisões orçamentais à racionalidade económica, p. 385-388.

148 MONCADA, Luís S. Cabral de. Perspectivas do novo direito orçamental português, p. 65.

${ }^{149}$ MONCADA, Luís S. Cabral de. Perspectivas do novo direito orçamental português, p. 71-72. 
muitas vezes constando do próprio texto constitucional, para setores específicos, como a seguridade social, cujos objetivos são estabelecidos no art. 194, parágrafo único, apenas para citar um exemplo. Outras vezes, em legislação específica, como a que institui o Plano Nacional de Educação. Aparecem também em planos nacionais e regionais de desenvolvimento, na forma do planejamento econômico governamental previsto no art. 174 da Constituição. E também nos próprios planos plurianuais, quando fixam as diretrizes, os objetivos e as metas da administração pública. Não que isso ocorra de maneira absolutamente clara, uma vez que nesses exemplos, com exceção de alguns planos plurianuais, os objetivos não são fixados de forma quantificada.

A segunda fase, da "programação", guarda uma correspondência com os nossos planos plurianuais, em que são elaborados os programas de caráter mais abrangente, ${ }^{150}$ de modo a delimitar e organizar os meios necessários para alcançar os objetivos. Novamente reparamos que se trata de uma correspondência não absolutamente precisa, pois, como se constata do conteúdo atribuído pela autora à citada fase, esta seria posterior à definição das missões e objetivos, que não é exatamente o que ocorre na hipótese ora explicitada, na medida em que os planos plurianuais muitas vezes, ainda que no âmbito específico de cada ente federado, também compreendem a definição de missões e objetivos. De qualquer forma, o paralelismo, ainda que ressalvadas essas imprecisões, é válido.

A terceira fase - "orçamentação" -, em que as decisões já estão tomadas, compreende o cálculo, a organização e a alocação dos recursos, o que se ajusta com razoável precisão à nossa lei orçamentária anual. Pode-se compreender também nesse processo a atuação da Lei de Diretrizes Orçamentárias, que, na sua principal função, exerce o papel de "elo" entre o PPA e a LOA, separando, dos grandes programas fixados no PPA, aqueles que serão contemplados - ou a parte deles que será contemplada - a cada orçamento anual.

Da mesma forma que nos itens anteriores, não se trata de uma correspondência exata, na medida em que não se pode considerar que, na elaboração da lei orçamentária, as decisões já tenham sido tomadas. De fato, decisões com natureza de planejamento de prazo mais longo já estão definidas em outros documentos. Mesmo assim, a própria lei orçamentária exige a tomada de decisões relevantes, que podem também impactar no sistema de planejamento, ainda que menos intensamente.

150 É o caso, por exemplo, dos "Programas Temáticos" que constam do Plano Plurianual federal 2012-2015. 


\subsection{EXCURSO: CONCEITOS RELEVANTES \\ PARA A COMPREENSÃO DOS MODELOS E TÉCNICAS ORÇAMENTÁRIOS}

Ver-se-á que a evolução do orçamento público volta-se em direção à busca de melhores resultados, ${ }^{151}$ e o caminho nesse sentido passa por uma série de conceitos e expressões que serão (e foram) utilizados ao longo da exposição, de uso muitas vezes multidisciplinar, o que eventualmente pode importar em maior dificuldade em delimitar o exato conteúdo. No mais das vezes, conceitos próprios da Administração Pública, também utilizados por economistas e juristas, nem sempre precisos, alguns dos quais objeto de controvérsia pelos especialistas nas áreas do conhecimento próprias. Em muitos dos conceitos, como se nota, há tautologias e referências recíprocas das expressões, além de outros problemas que em muito dificultam sua compreensão e delimitação. Por essa razão o objetivo desses esclarecimentos ora feitos é tão somente propor uma explicação, ainda que breve e desprovida de profundidade teórica exigível para os especialistas no tema, mas que se faz necessária para a compreensão dos temas que serão tratados ao longo deste trabalho, cuja preocupação central são os aspectos jurídicos, mas dependentes desses conceitos, dada a intensa interdisciplinaridade presente. E que não tem a pretensão de produzir definiçõos, o que exigiria um aprofundamento em temas que não são o foco do trabalho, motivo pelo qual se pretende tão somente expor ideias que permitam melhor delinear o conteúdo das expressóes selecionadas.

Ainda que as definições que ora se procura esclarecer não sejam precisas - o que se evidencia pelas divergências entre os próprios estudiosos que se voltam às áreas específicas -, é relevante adensá-las, a fim de que possam ao menos ser mais bem delimitadas, sem o que a compreensão de seu conteúdo ficaria por demais prejudicada. Ver-se-á ainda ao longo do trabalho que a própria legislação pátria não tem rigor metodológico na utilização das referidas expressões, produzindo normas que ora utilizam termos com um significado, ora com outro, muitas vezes na mesma unidade da federação, causando dificuldades de compreensão, compatibilização e aplicação das referidas normas. Uma falha que tem causado prejuízo para a implantação de um coerente sistema de planejamento, especialmente orçamentário, da administração pública.

Os termos referidos, independentemente da natureza estranha ao Direito Financeiro que muitas vezes representam, passaram a ter uma dimensão de importância

151 Analisado por Emerson Gomes com bastante propriedade pela ótica da dimensão do resultado do gasto público (GOMES, Emerson C. S. O direito dos gastos públicos no Brasil, p. 297-318). 
jurídica, na medida em que atualmente as leis de natureza orçamentária, especialmente a Lei Orçamentária Anual e o Plano Plurianual, utilizam-se deles para compor seu texto e anexos, construídos em torno de programas que contêm objetivos, metas, resultados, diretrizes, iniciativas, cuja mensuração realiza-se por meio de critérios de eficiência, eficácia, efetividade e economicidade, razão pela qual tais termos foram e devem necessariamente ser incorporados ao ordenamento jurídico, que deles não pode mais se distanciar. E conceitos como eficiência foram incorporados ao ordenamento e erigidos expressamente à estatura de princípios constitucionais (Constituição Federal, art. 37, caput), o mesmo ocorrendo com outros, como legitimidade e economicidade, também presentes no texto constitucional (Constituição Federal, art. 70).

As variaçõos das técnicas orçamentárias e sua evolução têm em vista o aperfeiçoamento dos modelos de planejamento e orçamento, visando a melhorar o desempenho da Administração Pública, e buscam, entre outras melhorias, o aumento da eficiência, eficácia, efetividade e economicidade no uso do dinheiro público.

Inicialmente, serão abordadas as expressões que ficaram conhecidas como "os 4 E's": eficiência, eficácia, efetividade e economicidade, que "correspondem a diferentes dimensões dos resultados, expressos por relações entre os inputs, outputs e outcomes", ${ }^{152}$ estas últimas expressões que serão analisadas na sequência.

A eficiência foi erigida à condição de princípio constitucional norteador da administração pública, passando a constar expressamente do texto constitucional, no caput do art. 37, a partir da Emenda Constitucional n. 19, de 1998, embora já constasse em normas infraconstitucionais anteriormente a essa data.

É um princípio jurídico que prega a rapidez, presteza, precisão e perfeição na prestação de serviços públicos, conforme ressaltam os estudiosos do Direito Administrativo. Para Odete Medauar, "a Administração deve agir, de modo rápido e preciso, para produzir resultados que satisfaçam as necessidades da população", ${ }^{153}$ em sentido semelhante ao que prega Hely Lopes Meirelles, segundo o qual o princípio da eficiência "exige que a atividade administrativa seja exercida com presteza, perfeição e rendimento funcional", ${ }^{154}$ não divergindo de Carvalho Filho, para quem "o núcleo do princípio é a procura de produtividade e economicidade e, o que é mais importante, a exigência de reduzir os desperdícios de dinheiro público, o que impõe a execução dos serviços públicos com presteza, perfeição e rendimento

152 GOMES, Emerson Cesar da Silva. O direito dos gastos públicos no Brasil, p. 303.

153 MEDAUAR, Odete. Direito administrativo moderno, p. 152.

154 MEIRELLES, Hely Lopes. Direito administrativo brasileiro, p. 98. 
funcional. ${ }^{155}$ Diogo de Figueiredo Moreira Neto evidencia o fato de que este conceito pode ser visto sob mais de uma óptica, tendo surgido inicialmente fora da Ciência do Direito, passando pela Economia e pela Administração Pública e, juridicamente, no âmbito do Direito Administrativo, pode-se entender a eficiência administrativa como "a melhor realização possivel da gestão dos interesses públicos, posta em termos de plena satisfação dos administrados com os menores custos para a sociedade", sendo um "atributo técnico da administração", "uma exigência ética a ser atendida, no sentido weberiano de resultados", "como uma característica jurídica exigível, e boa administração dos interesses públicos" (grifos do original). ${ }^{156}$

A noção de eficiência, quando mais voltada ao âmbito da administração, ressalta o melhor uso dos insumos na produção de bens e serviços:

"A eficiência é definida como a relação entre os produtos (bens e serviços) gerados por uma atividade e os custos dos insumos empregados para produzi-los, em um determinado período de tempo, mantidos os padrões de qualidade. Essa dimensão refere-se ao esforço do processo de transformação de insumos em produtos. Pode ser examinada sob duas perspectivas: minimização do custo total ou dos meios necessários para obter a mesma quantidade e qualidade de produto; ou otimização da combinação de insumos para maximizar o produto quando o gasto total está previamente fixado (Cohen; Franco, 1993). Nesse caso, a análise do tempo necessário para execução das tarefas é uma variável a ser considerada. A eficiência pode ser medida calculando-se e comparando-se o custo unitário da produção de um bem ou serviço. Portanto, podemos considerar que o conceito de eficiência está relacionado ao de economicidade". ${ }^{157}$

O conceito de eficiência, em uma análise minuciosa, evidencia uma complexidade que se intensifica na medida em que se aprofunda na busca de uma maior precisão, admitindo, inclusive, vários desdobramentos, como demonstra o documento produzido pelo governo australiano para orientar a administração pública, no qual se encontram os conceitos de eficiência econômica, eficiência produtiva, eficiência alocativa e eficiência dinâmica, cuja análise extrapola os limites do que é necessário para o presente trabalho, ficando apenas o breve registro. ${ }^{158}$

Emerson Gomes sintetiza com base nos aspectos mais destacados pela administração pública: "a eficiência corresponde à relação entre os inputs e os outputs. Mede a relação entre os bens e serviços produzidos e os recursos utilizados". ${ }^{159}$

155 CARVALHO FILHO, José dos Santos. Manual de direito administrativo, p. 32.

156 MOREIRA NETO, Diogo de Figueiredo. Curso de direito administrativo, p. 115-116.

157 BRASIL. Tribunal de Contas da União. Manual de auditoria operacional, p. 12.

158 AUSTRALIAN GOVERNMENT, Productivity Commission. On efficiency and effectiveness: some definitions, p. 3 (box 1).

159 GOMES, Emerson Cesar da Silva. O direito dos gastos públicos no Brasil, p. 303. 
A eficácia, conceito próprio da Administração, compreende ideia voltada ao cumprimento de objetivos e metas previamente estabelecidos. Pode ser definida como

"o grau de alcance das metas programadas (bens e serviços) em um determinado período de tempo, independentemente dos custos implicados (Cohen; Franco, 1993). O conceito de eficácia diz respeito à capacidade da gestão de cumprir objetivos imediatos, traduzidos em metas de produção ou de atendimento, ou seja, a capacidade de prover bens ou serviços de acordo com o estabelecido no planejamento das ações". ${ }^{160}$

Conceitos que não devem ser confundidos, principalmente em se priorizando a eficácia na atuação da administração pública, como esclarece Nazaré Cabral:

"Mas para além disto - e avançando um pouco mais -, é usual aparecerem confundidos os conceitos de eficiência e eficácia, quando na verdade eles têm significados diferentes e deverão, para alguns, ter graus de prioridade distintos. Na verdade, há quem considere que o objetivo fundamental (v.g. prioritário) da Administração Pública não é a eficiência ou a economia de meios. Mais importante é o objectivo da eficácia, ou seja, a maior aproximação possível dos resultados efectivamente alcançados aos resultados desejados. E vai-se mais longe, considerando-se que, em bom rigor, uma boa Administração não pode ter a eficiência como objectivo fundamental, pois não é essa, intrinsecamente, a sua vocação". ${ }^{161}$

Efetividade, conceito também próprio da administração, relaciona-se com o alcance dos resultados, no sentido de atingir os objetivos finalísticos programados, com a produção dos efeitos desejados, sendo voltado ao aspecto qualitativo dos serviços públicos.

"A efetividade diz respeito ao alcance dos resultados pretendidos, a médio e longo prazo. Refere-se à relação entre os resultados de uma intervenção ou programa, em termos de efeitos sobre a população-alvo (impactos observados), e os objetivos pretendidos (impactos esperados), traduzidos pelos objetivos finalísticos da intervenção. Trata-se de verificar a ocorrência de mudanças na população-alvo que se poderia razoavelmente atribuir às ações do programa avaliado (Cohen; Franco, 1993). Portanto, ao examinar a efetividade de uma intervenção governamental, pretende-se ir além do cumprimento de objetivos imediatos ou específicos, em geral consubstanciados em metas de produção ou de atendimento (exame da eficácia da gestão). Trata-se de verificar se os resultados observados foram realmente causados pelas ações desenvolvidas, e não por outros fatores (ISSAI 3000/1.5, 2004). A avaliação da efetividade pressupõe que bens e/ou serviços foram ofertados de acordo com o previsto. O exame da efetividade ou avaliação de impacto requer tratamento metodológico específico

160 BRASIL. Tribunal de Contas da União. Manual de auditoria operacional, p. 12.

161 CABRAL, Nazaré da Costa. Programação e decisão orçamental. Da racionalidade das decisões orçamentais à racionalidade económica, p. 447. 
que busca estabelecer a relação de causalidade entre as variáveis do programa e os efeitos observados, comparando-os com uma estimativa do que aconteceria caso o programa não existisse (ISSAI 3000/1.7, 2004)" ${ }^{162}$

São conceitos bastante próximos, mas que podem ser distinguidos, como observamos em Carvalho Filho:

"A eficiência não se confunde com a eficácia nem com a efetividade. A eficiência transmite sentido relacionado ao modo pelo qual se processa o desempenho da atividade administrativa; a ideia diz respeito, portanto, à conduta dos agentes. Por outro lado, eficácia tem relação com os meios e instrumentos empregados pelos agentes no exercício de seus misteres na administração; o sentido aqui é tipicamente instrumental. Finalmente, a efetividade é voltada para os resultados obtidos com as ações administrativas; sobreleva nesse aspecto a positividade dos objetivos. O desejável é que tais qualificações caminhem simultaneamente, mas é possível admitir que haja condutas administrativas produzidas com eficiência, embora não tenham eficácia ou efetividade. De outro prisma, pode a conduta não ser muito eficiente, mas, em face da eficácia dos meios, acabar por ser dotada de efetividade. Até mesmo é possível admitir que condutas eficientes e eficazes acabem por não alcançar os resultados desejados; em consequência, serão despidas de efetividade". ${ }^{163}$

Mauro Giacobbo segue na mesma linha, explicitando-o em poucas palavras, que permitem rápida compreensão, no texto em que discorre sobre o planejamento:

"A efetividade, muitas vezes, é tomada como sendo a combinação de eficiência e eficácia. Entretanto, ser eficiente e eficaz não garante efetividade. A eficiência está relacionada à tarefa, ao processo, ao 'fazer certo as coisas'; a eficácia está ligada ao produto, ao 'fazer as coisas certas'; e a efetividade está relacionada ao 'resultado verdadeiro', ao atendimento da necessidade do cliente/cidadão, ao cumprimento da finalidade". ${ }^{164}$

Em sentido semelhante, encontramos a explicação de Marc Robinson, quando mostra haver significados que diferem conforme a área do conhecimento que faz uso desses termos, ao esclarecer a distinção presente entre eficiência e efetividade, conceitos usados na literatura de administração pública e pelos economistas de forma diversa. A efetividade relaciona-se com os outcomes, ao passo que a eficiência, aos outputs (sobre essas expressões, ver item seguinte); a eficiência vincula-se ao sucesso em entregar o bem ou serviço ao menor custo, com a mesma qualidade, ao passo que a efetividade está vinculada à obtenção dos resultados pretendidos. ${ }^{165}$

162 BRASIL. Tribunal de Contas da União. Manual de auditoria operacional, p. 12.

163 CARVALHO FILHO, José dos Santos. Manual de direito administrativo, p. 34.

164 GIACOBBO, Mauro. O desafio da implementação do planejamento estratégico nas organizações públicas, p. 96-97.

165 ROBINSON, Marc. Results information. Performance budgeting. Linking funding and results, p. 29. 
O documento produzido pelo Ministério do Planejamento para orientar a gestão do PPA federal 2004-2007 evidencia também as distinções entre as expressões, com enfoque mais voltado à administração e ao planejamento:

"A efetividade, entendida como a correspondência entre a implementação de um Programa e o alcance do seu objetivo, tendo por referência os impactos na sociedade; eficácia, entendida como a capacidade de alcance das metas previstas para as ações do Programa; eficiência, garantida pelo uso otimizado, com economia e qualidade, dos bens e recursos empregados na execução das açôes, tendo por referência padrốes estabelecidos". ${ }^{166}$

Interessante, para efeitos ilustrativos e exemplificativos, registrar trecho do parecer emitido pelo Tribunal de Contas da União (TCU) no Relatório sobre as contas do governo de 2012, referindo-se à saúde:

"Para análise dos resultados alcançados pela atenção básica em 2012, foram selecionados metas, indicadores de eficácia (cobertura das equipes de agentes comunitários, cobertura das equipes de saúde bucal, cobertura das equipes de saúde da família, cobertura do Programa Saúde na Escola - PSE) e efetividade (taxa de mortalidade infantil, a razão de mortalidade materna, e a esperança de vida ao nascer e proporção de internações por causas sensíveis a atenção básica - Isab) constantes no PPA 20122015, no PNS 2012- 2015 e no Coap, relacionados direta ou indiretamente com a atenção básica" (grifo nosso). ${ }^{167}$

O Ministério do Planejamento, no documento produzido para orientar a gestão pública a construir indicadores voltados à avaliação de desempenho, seguindo recomendações do TCU, ${ }^{168}$ é também claro e exemplificativo ao explicitar os conceitos das expressões:

"Essa classificação (referindo-se aos indicadores de avaliação de desempenho) possui foco maior na avaliação dos recursos alocados e dos resultados alcançados. Segundo essa ótica, os indicadores podem ser de (TCU, 2000): Economicidade: medem os gastos envolvidos na obtenção dos insumos (materiais, humanos, financeiros etc.) necessários às ações que produzirão os resultados planejados. Visa a minimizar custos sem comprometer os padrões de qualidade estabelecidos e requer um sistema que estabeleça referenciais de comparação e negociação; Eficiência: essa medida possui estreita relação com produtividade, ou seja, o quanto se consegue produzir com os

166 BRASIL. Ministério do Planejamento. Secretaria de Planejamento e Investimentos Estratégicos. Plano de Gestão do PPA 2004-2007, p. 13.

167 BRASIL. Tribunal de Contas da União. Relatório e parecer prévio sobre as contas do Governo da República. Exercício 2012, p. 521.

168 E mencionadas pelo órgão no relatório de avaliação do PPA 2012-2015 - Acórdão 1.012/2013 (BRASIL. Tribunal de Contas da União. Acórdão 1.012/2013 - TCU - Plenário, Rel. Min. José Jorge, sessão de 24.4.2013). 
meios disponibilizados. Assim, a partir de um padrão ou referencial, a eficiência de um processo será tanto maior quanto mais produtos forem entregues com a mesma quantidade de insumos, ou os mesmos produtos e/ou serviços sejam obtidos com menor quantidade de recursos; Eficácia: aponta o grau com que um Programa atinge as metas e objetivos planejados, ou seja, uma vez estabelecido o referencial (linha de base) e as metas a serem alcançadas, utilizam-se indicadores de resultado para avaliar se estas foram atingidas ou superadas; Efetividade: mede os efeitos positivos ou negativos na realidade que sofreu a intervenção, ou seja, aponta se houve mudanças socioeconômicas, ambientais ou institucionais decorrentes dos resultados obtidos pela política, plano ou programa. É o que realmente importa para efeitos de transformação social". ${ }^{169}$

José Celso Cardoso Jr. chama a atenção para a maior importância que se deve dar à eficácia e efetividade das políticas públicas, muito mais do que à eficiência:

"Em linguajar técnico: jamais se sairá do debate pequeno sobre eficiência da gestão, para as categorias realmente relevantes da eficácia e efetividade das políticas públicas. Desde logo, políticas públicas que transformam. (...) Por fim, é preciso que a implementação das políticas públicas e a entrega efetiva de bens e serviços do Estado à população sejam os verdadeiros critérios de aferição e perseguição do desempenho institucional (setorial, territorial e agregado) do Estado brasileiro. Apenas dessa maneira se poderá, de fato, calibrar as ações de planejamento no sentido dos resultados intermediários (medidos pela eficácia da ação governamental) e dos resultados finais (medidos pela efetividade transformadora da ação) das políticas públicas nacionais, rumo à consolidação de um projeto de desenvolvimento integral para o Brasil do século XXI". ${ }^{170}$

O médico Roberto Passos Nogueira, que se dedica ao tema da saúde coletiva, ao analisar a aplicação dos conceitos na área da saúde, explica e exemplifica, deixando claro como se evidenciam as diferenças entre a eficiência e a efetividade aplicadas a uma política pública:

"O debate sobre a necessidade de conferir maior autonomia à gerência financeiro-administrativa das unidades assistenciais do SUS põe em relevo um contraste entre dois tipos de reforma administrativa do Estado. De um lado, encontra-se a reforma de tipo clássico, de inspiração thatcheriana, que almeja, antes de tudo, a eficiência no uso dos recursos públicos: fazer mais com menos, evitar o desperdício. De outro lado, está aquele modo de reforma que, sem desprezar as questôes de eficiência, busca primariamente alcançar efetividade, quer dizer, prestar serviços públicos com acesso garantido e mais amplo, em conformidade com as necessidades dos cidadãos". ${ }^{171}$

169 BRASIL. Ministério do Planejamento, Orçamento e Gestão. Secretaria de Orçamento Federal. Secretaria de Planejamento e Investimentos Estratégicos. Indicadores - orientações básicas aplicadas à gestão pública, p. 22.

170 CARDOSO JR., José Celso. Princípios e propostas para o PPA 2016-2019, p. 20-21.

171 NOGUEIRA, Roberto P. O desenvolvimento federativo do SUS e as novas modalidades institucionais de gerência das unidades assistenciais: gestão pública e relação público-privado na saúde, p. 25. 
Em síntese, o que se pode constatar é que a eficiência, em seu aspecto administrativo, corresponde à ideia de usar bem os recursos disponíveis; juridicamente, na obrigação de prestar serviços públicos de forma rápida e precisa. A eficácia traduz-se na capacidade de realizar objetivos imediatos. E a efetividade compreende a capacidade de agir de modo a transformar a situação existente, produzindo os efeitos desejados.

A economicidade é conceito com status constitucional, expressamente referido no art. 70 da Constituição da República, quando se refere à fiscalização da administração pública, que deve ser exercida "quanto à legalidade, legitimidade economicidade, aplicação de subvenções e renúncia de receitas" (grifo nosso).

A economicidade, por vezes referida até mesmo como um princípio, como faz Márcia Mata em texto sobre o tema,

“é um instrumento de averiguação da relação gasto público e benefício auferido, a ser empregado na subjetividade de cada caso, pois a medida da economicidade só pode ser verificada a partir da realidade de um determinado fato administrativo, onde possamos a partir de determinada verba examinarmos se os benefícios foram ou não alcançados, ou se ocorreu algum tipo de desvio, que impossibilitou o atingimento da finalidade perquirida pela Administração Pública”.

E a "economicidade traduz antes de tudo um compromisso econômico com o cumprimento de metas governamentais, inseridas na equação custo e benefício, onde a eficiência e a eficácia estão introduzidas como finalidade última de toda e qualquer receita destinada a um interesse público". ${ }^{172}$

Para o TCU, a "economicidade é a minimização dos custos dos recursos utilizados na consecução de uma atividade, sem comprometimento dos padrões de qualidade. Refere-se à capacidade de uma instituição gerir adequadamente os recursos financeiros colocados à sua disposição". ${ }^{173}$ Há um consenso, como se vê, no sentido de que a ideia de economicidade está intrinsecamente ligada à relação custo-benefício, propondo a adequação na utilização dos insumos para alcançar os benefícios pretendidos com eles.

A síntese de Emerson Gomes permite relacionar as expressões de forma a ter uma dimensão comparativa sucinta e, ao mesmo tempo, esclarecedora:

"Os resultados do gasto público podem ser expressos por suas dimensões de desempenho: economicidade, eficácia, eficiência e efetividade. A economicidade está relacionada

172 MATA, Márcia F. Fiscalização da administração pública em face da economicidade. RT, p. 235-236.

173 BRASIL. Tribunal de Contas da União. Manual de auditoria operacional, p. 11. 
à aquisição dos insumos da ação administrativa nas melhores condições. A eficácia diz respeito ao grau de atingimento dos objetivos propostos. A eficiência diz respeito à relação entre os produtos e os insumos. A efetividade diz respeito ao impacto da ação governamental no público-alvo. Em razão disso, a economicidade é a que se aplica ao gasto público em sentido estrito e as demais se referem a todo o processo de concretização da despesa pública". ${ }^{174}$

Além dos “4 E’s” mencionados, destacam-se os conceitos que serão analisados a seguir.

Input é expressão cujo uso é corrente em sua língua original, sem tradução, e que pode ser compreendida como os insumos, ou "entradas", que abrangem o trabalho (conjunto de habilidades, experiência e conhecimento dos servidores), bens de capital (incluindo terrenos, edificações, veículos e equipamentos), ativos financeiros e ativos intangíveis (como a propriedade intelectual), que são utilizados para a produção dos bens finais. ${ }^{175}$ Em outras palavras, simplificadamente, representa os elementos que são utilizados para a produção do que se almeja.

Outputs são os bens ou serviços que os órgãos governamentais produzem para a sociedade, sendo "produto" 176 a forma mais próxima de defini-lo. Não se limitam aos bens tangíveis e serviços públicos prestados diretamente à sociedade; abrangem também aspectos intangíveis das ações sobre os órgãos governamentais, instituições e entidades envolvidas nas políticas públicas, podendo ser mensuradas e controladas quantitativa e qualitativamente, de modo que podem ser utilizadas para a gestão de desempenho, mais facilmente que os outcomes. ${ }^{177}$ Tendem a ser mais adequados para documentos como a lei orçamentária, em face da necessidade de indicadores e metas mais precisos e delimitados aos quais se associará a destinação de recursos. Output "indica o final de um processo de produção, respectivamente de transformação". ${ }^{178} \mathrm{O}$ output, ou "saída" é a medida do volume de algo que tenha sido produzido; o outcome é uma medida de qualidade. ${ }^{179}$ Os outputs não se vincu-

174 GOMES, Emerson Cesar da Silva. O direito dos gastos públicos no Brasil, p. 317.

175 OCDE. Working definitions, p. 2.

176 Produto, para fins orçamentários, tem sido definido nas leis de diretrizes orçamentárias federais como o "bem ou serviço que resulta da ação orçamentária" (Lei n. 13.408/2016 - LDO Uniāo 2017, art. 5, VI).

177 OCDE. Working definitions, p. 2.

178 PFEIFFER, Peter. O quadro lógico: um método para planejar e gerenciar mudanças. In: GIACOMONI, James; PAGNUSSAT, José Luiz (Org.). Planejamento e orçamento governamental, p. 153.

179 OSBORNE, David; GAEBLER, Ted. Reinventing government: how the entrepreneurial spirit is transforming the public sector, p. 161. 
lam necessariamente aos resultados esperados em termos de efeitos que se espera da intervenção, como os outcomes, como se verá a seguir.

Outcomes, que podem ser compreendidos como "objetivos", são os efeitos na sociedade dos outputs produzidos pelos órgãos governamentais. Os outcomes, intencionais ou não, em geral não são totalmente controláveis pelo governo, dependendo do grau de controle da influência de fatores externos sobre o objetivo em questão, da eficácia da execução e da qualidade das políticas. ${ }^{180} \mathrm{O}$ objetivo, conforme Pfeiffer, também chamado purpose ou outcome, visa a explicitar qual é o propósito da intervenção.

"Em lugar de descrever o que se pretende fazer, aqui é descrita aquela nova situação que se visa alcançar com a realização do projeto. Essa nova situação seria, na verdade, o efeito esperado da intervenção e, portanto, deve considerar também as mudanças de comportamento na atuação das pessoas que desejam melhorar a sua atual situação". ${ }^{181}$

Os outcomes representam os efeitos reais, ou seja, a capacidade de resolução dos problemas para os quais foram concebidos. ${ }^{182}$

Outputs e outcomes não se confundem, como esclarece e exemplifica Nazaré Cabral: "Enquanto os primeiros se referem aos bens e serviços providos a terceiros (desde logo aos utentes) pelo Estado, os segundos referem-se a alterações trazidas às pessoas, às estruturas sociais e ao ambiente físico envolvente por aqueles 'outputs' e outros factores. Exemplo, o tratamento de uma apendicite é um 'output', ao passo que o 'outcome' desejado é o restabelecimento completo do doente. Os 'inputs', por seu turno, são os recursos (trabalho, materiais, equipamentos, edifícios, etc.) usados pelos departamentos públicos na produção de 'outputs'". ${ }^{183}$

Rodrigo Faria sintetiza: "pode-se afirmar que outputs se referem aos produtos e serviços entregues à sociedade por uma dada intervenção estatal; por sua vez, outcomes representam os impactos gerados na sociedade em razão da implementação de determinada política pública". ${ }^{184}$

180 OCDE. Working definitions, p. 1.

181 PFEIFFER, Peter. O quadro lógico: um método para planejar e gerenciar mudanças, p. 151.

182 Nas palavras de Nazaré Cabral: "a acção administrativa deve ser avaliada tendo em conta não apenas os bens e serviços produzidos e prestados (os outputs), mas também os efeitos reais (os outcomes) quanto à capacidade de resolução dos problemas sociais, pois é para isso que estão concebidas, afinal, as políticas públicas" (Programação e decisão orçamental. Da racionalidade das decisões orçamentais à racionalidade económica, p. 447, nota de rodapé 1.013).

183 CABRAL, Nazaré da Costa. Programação e decisão orçamental. Da racionalidade das decisões orçamentais à racionalidade econômica, p. 558, nota de rodapé 1.248. Em sentido semelhante: ROBINSON, Marc. Results information, p. 26-27.

184 FARIA, Rodrigo Oliveira de. Orçamento por resultados: tendências, perspectivas e desafios, p. 347. 
Resultados "são aqueles bens ou serviços produzidos pelo projeto, isto é, pela organização responsável pelo projeto e pelas organizações ou grupos que participaram efetivamente da sua implementação. Os resultados descrevem o escopo do projeto, ou seja, descrevem aquilo que é gerenciável pelo projeto e o que é da responsabilidade de sua gerência". E, "enquanto o objetivo do projeto é um efeito desejado, mas foge do controle e da responsabilidade da gerência do projeto, o alcance dos Resultados tem de ser gerenciado de tal forma que possa ser atribuído aos esforços do projeto". ${ }^{185}$ É expressão que se equipara aos outcomes, como já antecipado.

Adriana Santos sintetiza, baseando-se na linguagem gerencial, que os inputs podem ser compreendidos como os insumos, os outputs como produtos e os outcomes como os "resultados intermediários". 186

Luiz Fernando Arantes Paulo reconhece a multiplicidade de conceitos de "resultado", mostrando preferência por aquele utilizado pela Organização das Nações Unidas (ONU), para quem resultado é uma alteração mensurável e descritível de um estado de coisas a partir de uma relação de causa e efeito. Assim, ele pode ser intencional ou não intencional, positivo ou negativo. São considerados três tipos de resultados: em relação a programas e projetos, os bens e serviços oferecidos (outputs); em relação ao plano estratégico, as alterações desejadas na realidade (outcomes); e os efeitos produzidos pela intervenção a longo prazo, diretos ou indiretos, desejados ou não (impacts). ${ }^{187}$

Para o Ministério do Planejamento, ${ }^{188}$ ao orientar a gestão para a construção de indicadores, explicita a ideia de forma a deixar clara a expressão, ao considerar "resultado" as "medidas (que) expressam, direta ou indiretamente, os benefícios no público-alvo decorrentes das ações empreendidas no contexto de uma dada política e têm particular importância no contexto de gestão pública orientada a resultados. São exemplos as taxas de morbidade (doenças), taxa de reprovação escolar e de homicídios" ${ }^{189}$

185 PFEIFFER, Peter. O quadro lógico: um método para planejar e gerenciar mudanças, p. 153.

186 "Nas açõos governamentais há uma relação de causa e efeito entre cinco elementos fundamentais: insumos, processos, produtos, resultados e impactos, em que um nível contribui para o outro. Assim, os insumos (inputs) utilizados nos processos levam à entrega de produtos (outputs), que geram a realização de resultados intermediários (outcomes), que contribuem para a modificação de uma realidade (impacto)" (SANTOS, Adriana. Monitoramento e avaliação..., p. 20).

187 PAULO, Luiz Fernando Arantes. Planejamento por resultados ancorado em competências: uma proposta para a saúde, p. 14.

188 Atual Ministério do Planejamento, Desenvolvimento e Gestão.

189 BRASIL. Ministério do Planejamento, Orçamento e Gestão. Secretaria de Orçamento Federal. Secretaria de Planejamento e Investimentos Estratégicos. Indicadores - orientações básicas aplicadas à gestão pública, p. 21. 
Os objetivos, como já se fez referência, guardam semelhança com a expressão outcome, indicando o que se pretende obter com determinada ação, considerando-se seus efeitos transformadores.

Para mostrar os conceitos acolhidos em nossa legislação, exemplifica-se com o que foi utilizado para a elaboração do PPA 2008-2011, no qual foi considerado, para fins de construção dos programas, objetivo aquilo que "expressa o resultado que se deseja alcançar, ou seja, a transformação da situação a qual o programa se propóe modificar. Deve ser expresso com concisão, precisão, evitando a generalidade, dando a ideia do que se pretende de forma clara, categórica e determinante". ${ }^{190}$

Já por ocasião do PPA 2012-2015, com a mudança de metodologia e a introdução do conceito de iniciativa, o objetivo passou a expressar "o que deve ser feito, refletindo as situações a serem alteradas pela implementação de um conjunto de iniciativas, com desdobramento no território". ${ }^{191}$

E no PPA 2016-2019, com a intensificação do enfoque no aspecto estratégico e nos programas temáticos voltados às políticas públicas, o objetivo passou a "expressar as escolhas de políticas públicas para a transformação de determinada realidade, orientando taticamente a atuação do governo para o que deve ser feito frente aos desafios, demandas e oportunidades impostos para o desenvolvimento do País e para a melhoria da qualidade de vida da população". ${ }^{192}$

As metas relacionam-se com o aspecto mensurável dos objetivos e resultados. São a "medida de alcance do objetivo, podendo ser de natureza quantitativa ou qualitativa, a depender das especificidades de cada caso". ${ }^{193}$ A legislação orçamentária fala especificamente em meta física, especificando-a como a "quantidade estimada para o produto no exercício financeiro". ${ }^{194}$

190 BRASIL, Manual de elaboração - Plano Plurianual 2008-2011, p. 42. E traz como exemplo ilustrativo: Programa - acesso à alimentação; Objetivo: Garantir à população em situação de insegurança alimentar o acesso à alimentação digna, regular e adequada à nutrição e manutenção da saúde humana.

191 BRASIL. Ministério do Planejamento, Orçamento e Gestão. Secretaria de Planejamento e Investimentos Estratégicos. Orientaçóes para elaboração do Plano Plurianual 2012-2015, p. 11.

192 BRASIL. Ministério do Planejamento, Orçamento e Gestão. Secretaria de Planejamento e Investimentos Estratégicos. Orientaçôes para a elaboração do Plano Plurianual 2016-2019, p. 11.

193 BRASIL. Ministério do Planejamento, Orçamento e Gestão. Secretaria de Planejamento e Investimentos Estratégicos. Orientaçôes para elaboração do Plano Plurianual 2012-2015, p. 24.

194 Lei n. 13.408/2016 - LDO União 2017, art. 5º, VIII. 
Indicadores são os critérios utilizados para mensurar o que está sendo realizado em cada programa, com a finalidade de verificar o alcance dos resultados fixados, permitindo que se possam aferir as diversas variáveis que se pretenda conhecer e medir, como o desempenho. "Um indicador é uma situação ou característica que serve como sinal comprobatório de um outro fato. Trata-se, no caso do QL, de uma descrição operacional dos objetivos e dos resultados em termos de quantidade e qualidade de um produto ou serviço para o grupo-objetivo, indicando ainda o tempo (ou prazo) e o local (ou espaço)" 195 e tem como funções

"esclarecer, evidenciar e concretizar o que se pretende alcançar com cada resultado ou objetivo. (...) Um indicador é mais do que uma meta quantitativa. (...) o indicador fornece informações sobre cinco aspectos: quantidade, qualidade, tempo (prazo), local e beneficiários. (...) os indicadores estabelecidos no QL estão sempre relacionados ao desempenho". ${ }^{196}$

Nazaré Cabral evidencia a distinção entre várias das expressões anteriormente mencionadas, mostrando que as diversas técnicas de orçamentação podem se diferenciar pela ênfase dada a cada uma delas:

"Os orçamentos podem colocar a ênfase nos inputs - receitas, pessoal, bens e equipamentos - ou nos outputs, ou seja, o nível de serviços que podem ser assegurados com aqueles inputs (ou até mesmo evidenciar os outcomes, como por exemplo a redução da pobreza) (neste sentido, Rubin, 2007: 142). Como nos explica esta mesma autora (idem: 142-144 (referindo-se a Rubin)), a distinção entre as duas perspectivas radica no facto de a primeira colocar o acento tónico na quantidade e no modo como as verbas são gastas (orçamento de meios), enquanto que a segunda acentua o que é produzido, e não tanto o modo como é produzido (orçamento de fins). Enquanto os orçamentos de inputs procuram estabelecer limites (dotações máximas) para cada categoria ou rubrica (item) de despesa, os orçamentos de outputs usam os inputs de forma mais flexível. A orçamentação baseada nos inputs é orientada pela preocupação de controlo orçamental, procurando assegurar bens e fornecimento de serviços necessários à realização e uma determinada tarefa. A orçamentação baseada nos outputs, diversamente, é orientada pela ótica da gestão: dado um determinado nível global de recursos (envelope financeiro), procura-se garantir a qualidade de serviços para um certo número de utilizadores. Cada forma de orçamentação usa também um conceito de planeamento diferente. No modelo de inputs, os gestores calculam quanto de cada tipo de recursos necessitarão para realizar suas tarefas ao longo do exercício orçamental; no modelo de outputs, os gestores procuram saber como irão realizar os objetivos especificados - a melhoria da saúde, da educação, etc.”. ${ }^{197}$

195 PFEIFFER, Peter. O quadro lógico: um método para planejar e gerenciar mudanças, p. 157.

196 PFEIFFER, Peter. O quadro lógico: um método para planejar e gerenciar mudanças, p. 171.

197 CABRAL, Nazaré da Costa. A teoria do federalismo financeiro, p. 253. 
Mostra ainda, em outro texto, a influência que podem ter na forma de construir o sistema de planejamento orçamentário governamental:

"Cada forma de orçamentação usa também um conceito de planeamento diferente. No modelo de inputs, os gestores calculam quanto de cada tipo de recurso necessitarão para realizar as suas tarefas ao longo do exercício orçamental; no modelo de outputs os gestores procuram saber como irão realizar objectivos especificados - a melhoria da saúde, da educação etc. (...) O pressuposto do modelo de outputs é o de custo-eficácia da medida: não está tão preocupado em saber quanto se gasta, mas mais com os resultados que os cidadãos retirarão da utilização dos seus dinheiros. (...) Os exemplos paradigmáticos do modelo de outputs são os orçamentos de programas (versão PPBS) e os orçamentos por objectivos". ${ }^{198}$

A iniciativa aparece como conceito relevante no PPA 2012-2015, que, na nova metodologia utilizada, passou a utilizá-lo para descrever "o atributo do Programa Temático que norteia a ação governamental e estabelece um elo entre o Plano e o Orçamento".

Com a finalidade de dar ênfase ao caráter estratégico do Plano Plurianual, o binômio "programa-ação" foi substituído por Programas Temáticos, que são compostos por Objetivos e Iniciativas, ficando a categoria de ação apenas para os orçamentos.

A iniciativa, assim, passou a representar um atributo do Programa Temático que "declara as entregas à sociedade de bens e serviços, resultantes da coordenação de ações orçamentárias e outras: ações institucionais e normativas, bem como da pactuação entre entes federados, entre Estado e sociedade e da integração de políticas públicas". ${ }^{199}$

Pela nova metodologia, as ações orçamentárias que comporão o orçamento são criadas a partir das iniciativas, de forma que

"para cada Iniciativa podem corresponder uma ou mais ações orçamentárias. Da mesma forma, pode haver mais de uma Iniciativa por Objetivo. A Iniciativa não se restringe a açôes orçamentárias. É possível que o financiamento se dê por outras fontes. Além das formas de financiamento, as Iniciativas consideram também como as políticas organizam os agentes e instrumentos que as materializam (dimensão associada à gestão, relação federativa, relação público-privada, critérios de adesão, condicionantes, priorizaçôes, mecanismos de seleção e identificação)". ${ }^{200}$

198 CABRAL, Nazaré da Costa. Orçamentação pública e programação: tendências internacionais e implicações sobre o caso português. In: CONTI, José Mauricio; SCAFF, Fernando F. (Coord.). Orçamentos públicos e direito financeiro, p. 649.

199 BRASIL. Ministério do Planejamento, Orçamento e Gestão. Secretaria de Planejamento e Investimentos Estratégicos. Orientações para elaboração do Plano Plurianual 2012-2015, p. 25.

200 BRASIL. Ministério do Planejamento, Orçamento e Gestão. Secretaria de Planejamento e Investimentos Estratégicos. Orientaçôes para elaboração do Plano Plurianual 2012-2015, p. 25. 
Tratando-se de metodologia implantada recentemente, vê-se estar ainda em aperfeiçoamento, não sendo isenta de críticas. O TCU já observou falhas conceituais na implantação, como se pode constatar no Acórdão 1.012/2013, resultado de avaliação nessa nova estrutura do PPA 2012/2015. Para o TCU,

"O conceito de iniciativa envolve a entrega de bens e serviços à sociedade, no entanto, observa-se que em algumas iniciativas do programa temático Bolsa Família, como, por exemplo, a de 'Fortalecimento da capacidade de gestão descentralizada do programa Bolsa Família', existe apenas uma declaração de intenção, não estando claro qual produto ou serviço será disponibilizado à sociedade. Pode-se inferir que tal fato representa uma falha na formulação das iniciativas, existindo a necessidade de que ocorra sua revisão, com a finalidade de adaptá-las ao conceito a elas atribuído”. ${ }^{201}$

Vê-se que a ideia de iniciativa é não restringir o conceito ao orçamento, mas ampliá-lo, de modo a admitir os recursos com os quais será financiada oriundos de outras fontes, como as já mencionadas (relações federativas, parcerias público-privadas etc.), o que é, em princípio, uma medida interessante, tendo em vista que se mostra mais adequada à realidade das políticas públicas hoje em curso, no mais das vezes de caráter multissetorial e interfederativo, com multiplicidade de formas e fontes de financiamento.

201 BRASIL. Tribunal de Contas da União. Acórdão 1.012/2013 - TCU - Plenário, Rel. Min. José Jorge, sessão de 24.4.2013, p. 22, item 97. 